NBER WORKING PAPER SERIES

\title{
THE EFFECTS OF GOING PUBLIC ON FIRM PERFORMANCE AND COMMERCIALIZATION STRATEGY: EVIDENCE FROM INTERNATIONAL IPOS
}

\author{
Borja Larrain \\ Gordon M. Phillips \\ Giorgo Sertsios \\ Francisco Urzúa \\ Working Paper 29219 \\ http://www.nber.org/papers/w29219
NATIONAL BUREAU OF ECONOMIC RESEARCH
1050 Massachusetts Avenue
Cambridge, MA 02138
September 2021

We thank comments and suggestions from Reena Aggarwal, Sreedhar Bharath, Murray Carlson, Sonia Falconieri, Naveen Khanna, Max Maksimovic, Amiyatosh Purnanandam, and seminar participants at the Virtual Corporate Finance Seminar, the Bocconi-St. Gallen Conference on Owners as Strategists, and the 2021 China International Conference in Finance. Larrain acknowledges funding from Proyecto Fondecyt Regular \#1180593. We also thank Augusto Orellana for excellent research assistance. The views expressed herein are those of the authors and do not necessarily reflect the views of the National Bureau of Economic Research.

NBER working papers are circulated for discussion and comment purposes. They have not been peer-reviewed or been subject to the review by the NBER Board of Directors that accompanies official NBER publications.

(C) 2021 by Borja Larrain, Gordon M. Phillips, Giorgo Sertsios, and Francisco Urzúa. All rights reserved. Short sections of text, not to exceed two paragraphs, may be quoted without explicit permission provided that full credit, including ()$^{\text {notice, }}$ is given to the source. 
The Effects of Going Public on Firm Performance and Commercialization Strategy: Evidence from International IPOs

Borja Larrain, Gordon M. Phillips, Giorgo Sertsios, and Francisco Urzúa

NBER Working Paper No. 29219

September 2021

JEL No. G32

\section{ABSTRACT}

We study the effects of going public using a unique panel of firms in 16 European countries for which we observe financial data before and after firms' initial-public-offering (IPO) attempts. We compare firms that complete their IPO with firms that withdraw their IPO. We instrument the going public decision using prior market returns. We find that firm profitability goes up after going public_-contrary to previous results in the literature. We also find an post-IPO expansion in the number of subsidiaries and countries in which IPO firms operate. Our results are stronger for firms in financially dependent industries and in countries with higher investor protection consistent with going public relaxing financial constraints and with a stronger impact when agency conflicts are lower. Overall, our results are consistent with going public inducing a shift towards a strategy of commercialization to increase profitability.

Borja Larrain

Escuela de Administracion

Pontificia Universidad Catolica de Chile

Avda Vicuna Mackenna 4860

Macul, Santiago

Chile

borja.larrain@uc.cl

Gordon M. Phillips

Tuck School of Business

Dartmouth College

100 Tuck Hall

Hanover, NH 03755

and NBER

gordon.m.phillips@gmail.com
Giorgo Sertsios

University of Wisconsin Milwaukee

Lubar School of Business

3202 N Maryland Ave

Milwaukee, WI 53202

sertsios@uwm.edu

Francisco Urzúa

City University of London

Cass Business School

London

United Kingdom

francisco.urzua@city.ac.uk 


\section{Introduction}

Going public is a key decision for many firms. Explanations for why firms go public include diversification and liquidity for previous owners, as well as to raise capital for expansion. There are conflicting benefits and costs of going public. There is the positive effect of additional capital that allows the firm to undertake new investment opportunities. There are also potential agency costs as going public changes concentrated ownership to dispersed ownership where the incentives of managers and investors can diverge (Jensen and Meckling, 1976), or managers faced with stock market pressure can become myopic (Stein, 1989). The stylized fact in the literature so far is that, on average, profitability falls after IPOs, which seems to speak against the benefits of public status (Degeorge and Zeckhauser 1993, Jain and Kini 1994, Mikkelson, Partch, and Shah 1997). In addition, Bernstein (2015) shows that IPO firms have lower patenting rates and fewer citations after going public. These results could be interpreted as as evidence of short-termism or agency costs of being public (Kahle and Stulz, 2017). However, going public might alternatively be associated with an optimal change in strategy to raise funds for commercialization and also to focus on increasing profitability. Our paper explores whether this shift in strategy is associated with going public.

In order to provide a definitive answer it is crucial to distinguish the selection and causal effects of going public. Selection means that firms time their IPO decisions according to their life-cycle, profitability shocks, or industry shocks (Pástor, Taylor, and Veronesi 2009 , Spiegel and Tookes 2020, Maksimovic, Phillips, and Yang 2020). The dynamics of these other variables can explain many post-IPO outcomes, and not going public in itself. The true causal effect of going public, instead, refers to changes that happen to firms because they go public, and not simply changes that are correlated with the going public decision. Maksimovic, Phillips, and Yang (2020) argue that the causal effect of going public can be as big as the selection effect. However, isolating and estimating this causal effect has been elusive. In this paper we try to fill this gap.

Our empirical design sheds light on the rationale and consequences of going public in two 
ways. First, we collect novel data on firms' commercialization activities as well as data on firms that withdraw their IPOs from the market, which represent a reasonable counterfactual for firms that go public and allow us to control for a host of self-selection issues. Our sample of approximately 3,400 firms, spread across 16 European countries between 1997 and 2017, contains pre- and post-IPO-attempt information irrespective of whether firms complete or withdraw their IPO. In particular, the post-withdrawal profitability of private firms has not been available in the previous literature. The panel structure of the data allows us to include firm fixed effects and therefore to control for all time-invariant characteristics at the firm level.

We use withdrawn IPOs as counterfactual for completed IPOs, but the decision to withdraw is still endogenous. Therefore, a second crucial element of the identification strategy is to instrument for the likelihood of IPO completion. In the same spirit as Bernstein (2015), we use market returns over the previous 30 days to instrument for the IPO decision. These 30 days coincide with the marketing and book-building phase of the IPO. Firms that pull their IPOs usually blame poor market conditions for the withdrawal. In line with previous evidence, we find that positive market returns in the previous 30 days increase the likelihood of IPO completion by $6.9 \%$ (from an unconditional probability of $87 \%$ ). The pre-choice return is basically uncorrelated with firm characteristics of candidate IPOs, so it is well-balanced as an instrument. Market returns in this short window are unlikely to directly affect firm outcomes several years after the attempt, which is what the exclusion restriction requires. In short, our identification strategy is based on the idea that good returns are simply a nudge for some firms that are at the margin between listing or not, but have no effect on the firm except for their impact on the going public decision.

We find that the OLS effect on profitability (return on assets, ROA) of completing an IPO versus withdrawing is basically zero. As in the previous literature, we find that the ROA of IPO firms goes down after going public. However, firms that withdraw their IPOs also experience a similar decline in profitability. This suggests that the previously documented 
post-IPO drop in profitability is related to selection issues or the choice of counterfactual.

We find in our instrumental variables (IV) estimation a significant increase in profitability associated with going public - evidence consistent with a shift to commercialization. Hence, when we isolate the arguably exogenous transitions to listed status we find a positive effect instead of negative effect. ROA in completed IPOs increases by close to one standard deviation of profitability in this sample. The effect is large, but plausible. We check that our setup is not affected by a weak-instrument problem, which could artificially increase the magnitude of the coefficients (Jiang, 2017). We show that our inference is robust to the exclusion of clusters of observations as recommended by Young (2021). In terms of theory, we can expect an IV coefficient that is larger than the OLS coefficient since selection effects induce a downward bias in OLS. In equilibrium, a large increase in profitability is likely to be needed to compensate for the equally large costs of going public (close to $5 \%$ of firm value according to Gahng, Ritter, and Zhang 2021).

Besides profitability, we find with our IV estimation that there is a large (but noisy) effect on asset growth and sales, and a large (and more precisely estimated) effect in the number of subsidiaries and the number of countries a firm operates in. In line with Bernstein (2015), we find that patenting falls after going public, particularly in countries with high levels of investor protection (Djankov, La Porta, López-de-Silanes, and Shleifer, 2008) and information disclosure (La Porta, López-de-Silanes, and Shleifer, 2006). Overall, our results suggest that going public is associated with shfiting firms away from exploration or innovation and towards commercialization where growth is focused on segments with strong margins that also have higher profitability $!^{1}$

In order to identify mechanisms we study the variation of our effects across industries and countries. We find that the increase in profitability is stronger in industries with high

\footnotetext{
${ }^{1}$ Although not in our sample, the IPO of Uber illustrates the shift to commercialization and how profitability can also be achieved by cutting non-performing segments. "Mr. Khosrowshahi (CEO) has moved to restructure Uber to deliver on a promise to make the company profitable, scaling back many of its expensive side businesses (...) The company has promised to be profitable on an adjusted basis before interest, taxes, depreciation and amortization by the end of next year (2021)." (Uber Sells Self-Driving-Car Unit to Autonomous-Driving Startup, Wall Street Journal, December 7, 2020).
} 
financial dependence (Rajan and Zingales, 1998). Although the average effect on asset growth is noisy, we find a positive and significant effect on the asset growth of firms in financially dependent industries, which supports the idea that relaxing financial constraints is one of the advantages of going public. The increases in profitability and asset growth are stronger in countries with high investor protection and disclosure requirements. These last results suggest that containing agency problems - giving voice and information to minority investors - is important to realize the benefits of becoming public. Related to this, we find that completed IPOs are more than simply capital raising since there are significant increases in executive turnover compared to withdrawn IPOs.

Finally, we conduct placebo tests that allow us, at least indirectly, to check the exclusion restriction of the IV strategy. For the instrument to be valid, short-run returns must be related to long-run outcomes only through the decision to complete the IPO. We use as placebo instruments the market returns that accrue after the short pre-decision window of 30 days. Placebo returns have no impact on the likelihood of IPO completion (1st stage), nor on future firm outcomes (reduced-form regressions). Hence, consistent with the exclusion restriction, if there is no impact on the ownership choice (1st stage), then there is no effect on firm outcomes (2nd stage). This is what one would expect under the exclusion restriction, because the channel of influence between returns and long-run outcomes is severed once listed status is fixed.

Our paper contributes, first and foremost, to the literature on the consequences of going public (Pagano, Panetta, and Zingales 1998, Kim and Weisbach 2008). We overcome several challenges in this literature including having data on firms pre-IPO and also data for withdrawn firms post-IPO. We also carefully account for selection issues given that data are usually available only for firms that choose to go public. More productive firms, firms with better governance, or firms with more investment opportunities, can self-select into public markets. In this paper, we focus on isolating the treatment effect of going public, i.e., does public status cause firm profitability and investment to go up? Estimating the treatment 
effect of going public is a first order question in corporate finance, which speaks directly of the advantages (or disadvantages) of accessing public markets.

Recent work also deals with the treatment effect of going public, focusing on outcomes such as innovation, institutional ownership, employment, and local spillovers (Bernstein 2015; Borisnov, Ellul, and Sevilir 2019; Butler, Fauver, and Sypiridopoulos 2019; Babina, Ouimet, and Zarutskie 2020; Cornaggia, Gustafson, Kotter, and Pisciotta 2020; Dambra, Gustafson, and Pisciotta 2021). Compared to previous work, we have access to panel data with financial variables for both completed and withdrawn IPOs, which allows us to study the long-standing puzzle of the post-IPO drop in profitability. Our results are stronger for firms in financially dependent industries and in countries with higher investor protection consistent with going public relaxing financial constraints and with a stronger impact when agency conflicts are lower.

Our results are also related to the literature that compares the performance of private and public firms. Asker, Farre-Mensa, and Ljungqvist (2015) argue that private firms react more to industry shocks than public firms. Gilje and Taillard (2016), with data for the natural gas industry, and Phillips and Sertsios (2017), with data for the medical devices industry, find the opposite using quasi-natural experiments. In general, the comparisons between private and public companies are blurred by selection issues. Our results contribute by estimating the pure treatment effect of going public, which can help bridging the gap between apparently contradictory results.

The rest of the paper is organized as follows. Section 2 describes the data. Section 3 explains the identification strategy behind our IV estimation. Section 4 reports the main IV results, placebo tests, and auxiliary results. Section 5 concludes. 


\section{Data}

\subsection{Sample Selection and Panel Structure}

Our data consist of 3,467 IPO attempts, out of which 3,037 are completed and 430 are withdrawn. Hence, the unconditional likelihood of IPO completion is $87 \%$. We arrive at this sample through the following procedure. From Dealogic, SDC, and Zephyr we obtain the dates of all IPO attempts between 1997 and 2017 in 16 European countries. These data vendors compile dates for IPO completions and withdrawals from regulators, stock exchanges, the financial press, and other outlets. We merge the list of IPO attempts with financial information for each firm from Amadeus, which reports data for public and, crucially, private firms. We get year-end financial information from two years before the IPO attempt to two years after the IPO attempt. This gives us a 5 -year event window from $t$ - 2 to $t+2$, where year $t$ is the year of the IPO attempt for each firm. We keep the IPO attempt only if we have financial data for years before and after the attempt. We drop observations if the 5-year event window overlaps with other IPO attempts, successful or withdrawn, for the same firm $2^{2}$

Figure 1 shows the distribution of IPO attempts by country and calendar year. As can be expected, bigger markets, such as the UK, Germany, or France, have more IPO filings $!^{3}$ There are peaks of IPO filings in 2000 and 2006-7, which coincide with years of high stock market valuations. The percentage of withdrawn IPOs also moves with the stock market cycle, with relatively more withdrawals in years of poor returns such as 2001, 2008, and 2010. In terms of country coverage and distribution across years, our sample is comparable to the one in Helbing, Lucey, and Vigne (2019) who also study IPOs in Europe. It is important to note that, given the relative decline of the U.S. IPO market (Doidge, Karolyi, and Stulz, 2013), the European market was probably the largest market for new issues in this sample

\footnotetext{
${ }^{2}$ We drop 52 withdrawn attempts that are followed by a completed IPO within the 5-year period. We also exclude 15 withdrawn attempts that are followed by another withdrawn attempt within the 5-year period. The appendix provides more details on our sample selection and details on withdrawn attempts.

${ }^{3}$ The main effects are robust to the exclusion of observations that represent cross-listings (298 observations as seen in column 5 of Table A.1 in the appendix.
} 
period.

\section{Insert Figure 1 here}

Figure 2 shows the distribution of the 14,410 firm-year observations by event year. Observations for completed and withdrawn IPOs are shown separately. The panel is not perfectly balanced as there are close to $15 \%$ fewer observations in the extreme years of the event window (years $t+2$ and $t$-2) than in the years adjacent to the IPO attempt (years $t$ and $t-1$ ). However, the panel for withdrawn IPOs is not more unbalanced than the panel for completed IPOs. There is attrition in the extreme years because firms do not have operating history so much in advance of their IPO attempts, or because firms disappear or get acquired later on!

\section{Insert Figure 2 here}

Table 1 shows summary statistics for the main variables in our analysis. The first three variables in the table make reference to the structure of the data. The average of the Completed IPO dummy implies that firms that eventually go public represent $87 \%$ of the firm-year observations. The Post dummy captures the post-attempt observations for completed and withdrawn firms. The average of $60 \%$ shows that typically there are 3 post-attempt years $(t, t+1$, and $t+2)$ and 2 pre-attempt years $(t-2$ and $t-1)$. The IPO dummy is the Completed IPO dummy times the Post dummy, and it captures the post-IPO period for the firms that go public. The average of the IPO dummy implies that $52 \%$ of the observations correspond to firms while they are publicly traded, and $48 \%$ correspond to firms while they are private.

Insert Table 1 here

\section{$2.2 \quad$ Firm-level Variables}

Return on assets (earnings before interest, taxes, depreciation, and amortization over book assets) is the main measure of profitability. In Table 1 we show that mean (median) ROA is

\footnotetext{
${ }^{4}$ Most European markets require at least three annual reports before listing. However, the UK AIM does not require a minimum operating history (Helbing, Lucey, and Vigne, 2019).
} 
$-2 \%(3 \%)$, but with a large standard deviation of $24 \%$. There are slightly fewer observations for ROA than for other variables because its computation requires information from both the income statement and the balance sheet of the firm. The coverage for income statements is not as good as for balance sheets due to variation in reporting standards across Europe. Average assets are 172 million Euros, but the size distribution is highly skewed to the right as implied by a much lower median assets of 10.6 million Euros. Something similar happens with firm sales. Asset growth is the main measure of investment since capital expenditures are rarely reported. Mean (median) asset growth is $59 \%(9 \%)$, which can be expected from high-growth firms that are considering an IPO to raise funds. From the ownership data provided by Amadeus, we measure firm scope using the number of subsidiaries operated by each firm and the number of countries where the headquarters and subsidiaries are located.

Besides financials, we also consider some long-term outcomes for each firm. Patents correspond to the number of patent applications that are eventually approved. These data comes from Zephyr, which matches firms and patent information from the European Patent Office. Acquisitions correspond to the number of firms that the firm acquires. Target is a dummy variable that takes a value of one if the firm is acquired within five years of the IPO. Acquisitions data also come from Zephyr. Since we want to compute long-term outcomes after the IPO attempt, for patents and acquisitions we use a forward-looking moving average of the next 3 years (e.g., in year $t$ we use the average of patents between years $t, t+1$, and $t+2) !^{5}$

We also employ several industry and country characteristics in our analysis. The external finance dependence of each industry, measured at the 3-digit SIC level, is taken from Rajan and Zingales (1998). At the country-level, the anti-self-dealing index is taken from Djankov, La Porta, López-de-Silanes, and Shleifer (2008), while the prospectus disclosure index is taken from La Porta, López-de-Silanes, and Shleifer (2006) ${ }^{6}$

\footnotetext{
${ }^{5}$ The results for patents and acquisitions are qualitatively similar if we use yearly observations instead of the forward-looking moving averages.

${ }^{6}$ Summary statistics for these variables are reported in Table A.2 in the appendix.
} 


\section{Empirical Design}

\subsection{OLS and Instrumental Variables (IV)}

We first estimate changes in firm-level outcomes around the IPO decision with the following differences-in-differences regression:

$$
Y_{i t}=\beta I P O_{i t}+\alpha_{i}+\alpha_{\tau}+\alpha_{j t}+\varepsilon_{i t}
$$

The dependent variable is measured for firm $i$ at the end of calendar year $t$. The main variable of interest is $I P O_{i t}$, which takes a value of 1 if firm $i$ has gone public in year $t$ or earlier, and 0 if the firm is still private. $I P O_{i t}$ is the dummy for completed attempts times the Postit dummy for the after-attempt period, hence it captures the before-and-after for completed IPOs relative to withdrawn IPOs. One of the advantages of the panel structure is that we can include firm fixed effects $\left(\alpha_{i}\right)$, and focus on within-firm variation. With the firm fixed effects we also avoid the need to control for initial conditions such as size, profitability, and others.7 The unbalanced nature of the panel suggests that it is necessary to control for event-time fixed effects $\left.\left(\alpha_{\tau}\right)\right|^{8}$ These fixed effects absorb the Post $t_{i t}$ dummy while also allowing us to control for life-cycle dynamics that are common to all IPO attempts (see, for example, Degeorge and Zeckhauser 1993). The industry-by-calendar-year fixed effects $\left(\alpha_{j t}\right)$ capture annual swings at the one-digit SIC level. $9^{9}$ For example, Spiegel and Tookes (2020) argue that more than $50 \%$ of IPO decisions are related to industry trends.

\footnotetext{
${ }^{7}$ Alternatively, one could collapse the panel into a pre-vs-post setting. In that case, and in order to level the field for cross-sectional comparisons, it is common to include in the regression firm-level initial characteristics (e.g., assets in t-2). However, this implies having a full set of control variables in the preattempt period. In our context, this would mean losing a quarter of the sample, and thus losing substantial power in the IV estimates we discuss later on.

${ }^{8}$ The event-time fixed effects include event-year dummies from $t$ - 2 to $t+2$ together with a calendar-month effect for the post-IPO-decision period. The calendar-month effect allows us to level the field for comparisons between firms that take the IPO decision in, say, January of year $t$ and firms that take the decision in, say, December of year $t$. It can be expected that firms taking the decision in December show little or no effect on their year-end outcomes in $t$ compared to firms that take the decision in January, hence the need to control for such mechanical differences.

${ }^{9}$ Our results are robust to including industry-by-year fixed effects when industries are defined at the two-digit SIC level. See column 6 in Table A.1 in the appendix.
} 
A causal interpretation of the OLS coefficient on $I P O_{i t}$ is problematic. For example, let's consider the case where $Y_{i t}$ is firm profitability. Along the lines of Pástor, Taylor, and Veronesi (2009), imagine that a positive shock to current profitability $\left(\varepsilon_{i t}\right)$ triggers the decision to complete the IPO. To the extent that there is mean reversion in profitability, future residuals in equation (1) will look unusually low (i.e., $\varepsilon_{i t+1}$ and others will be low). In other words, as the initial shock fades away, completed IPOs will show a larger drop in future profitability than withdrawn IPOs. The negative correlation between $I P O_{i t}$ and residuals introduces a downward bias in the OLS estimate of $\beta$. Hence, OLS does not capture the true causal effect of going public on profitability ${ }^{10}$

An indication of endogeneity is presented in Table 2. Panel A shows that, on average, firms that withdraw their IPOs are significantly more profitable and larger (both in terms of assets and sales), and have higher leverage than completed IPOs. This evidence is consistent with Busaba, Benveniste, and Guo (2001) who show that highly levered firms and firms with more sales are more likely to withdraw their IPOs in the U.S. These differences suggest that, even this late in the IPO process, firms self-select into listed status. For instance, although all firms in this sample have announced their intention to list, larger firms can be less financially constrained (Hadlock and Pierce 2010), and hence be more likely to withdraw their IPO.

\section{Insert Table 2 here}

In order to interpret the effect of going public in a causal way we need exogenous variation in the decision to complete the IPO. Exogenous does not mean totally random, as could be the hypothetical case of a stock market regulator who runs a lottery for firms that have been short-listed for an IPO, like there are lotteries for foreigners applying to get visas. Exogenous does not mean either that the firm is unaware of the consequences of going public, or that the firm is subsequently surprised by what going public entails. Similarly, visa applicants

\footnotetext{
${ }^{10}$ Another possibility is that IPO firms practice earnings management and inflate profitability before the IPO (Teoh, Welch, and Wong, 1998). In this case, the post-IPO period simply reveals the true nature of the firm, while the pre-IPO period is manipulated.
} 
are not unaware of what a visa implies. We need to clear a lower bar than that; namely, that the source of variation in IPO completion is uncorrelated with future firm outcomes except through the decision to complete the IPO.

Bernstein (2015) proposes as instrument for IPO completion the market returns in the pre-IPO-decision period. Bernstein (2015) uses returns on the two months that follow the IPO filing date with the SEC. There is no uniform rule in Europe for IPO filings, nor a unique form such as the SEC's Form S-1, so we need to count backwards from the actual date in which the decision to complete or withdraw the IPO is made. The typical IPO process starts approximately six months before the planned date, in most cases by contacting an investment bank. A preliminary prospectus is submitted to the stock market regulator about one or two months before the IPO. However, most of the IPO-related activities, such as presentation to analysts, investor education, roadshow, and book-building, are reserved for the last month before the planned date. We focus on the market returns over these 30 days that precede the IPO completion or withdrawal date 11 Since we have IPOs from several countries we use the returns for the main stock index in each country.

It is common for firms to blame "poor market conditions" for their decision to withdraw the IPO. There are rational and behavioral explanations for this behavior, although we do not take a stance as to which explanation is more appropriate. According to Edelen and Kadlec (2005), if owners are focused on reaching a certain level of proceeds, then strong prior returns increase the likelihood that owners accept the underpricing that affects most listings. Loughran and Ritter (2002) give a related explanation based on the prospect-theory preferences of owners. Finally, Derrien (2005) and Cornelli, Goldreich, and Ljungqvist (2006) argue that prior returns are a proxy for the mood or sentiment of IPO investors. Strong returns are a sign of overvaluation in this case. Irrespective of the particular explanation, strong market returns are likely to increase the willingness of owners to go through with the

\footnotetext{
${ }^{11}$ For example, if the IPO is on August 15, we compute the returns between July 15 and August 14. We study the impact of returns at different horizons in Table A.3 in the appendix. The previous 30 days have the strongest predictive power for the likelihood of IPO completion.
} 
listing. Naturally, this relationship does not need to be deterministic, as in no IPO being completed when returns are low. Rather, high and low returns need only affect the likelihood of completion for those firms at the margin between listing or not.

The first stage of the IV estimation is then:

$$
I P O_{i t}=\gamma \text { PreReturn }_{m} \times \text { Post }_{i t}+\alpha_{i}+\alpha_{\tau}+\alpha_{j t}+\zeta_{i t}
$$

In order to account for the time dimension in the panel we need to interact the market return in the pre-decision period $\left(\right.$ PreReturn $\left._{m}\right)$ with the indicator variable for the postdecision period $\left(\right.$ Post $\left._{i t}\right)$. This is necessary because the returns in the pre-decision period are only relevant to explain post-decision outcomes, and not whatever happened in, say, eventyear $t$ - 2 or $t$ - 1 . Bernstein (2015) runs only a cross-sectional regression of post-IPO-decision outcomes on a completed IPO indicator dummy (controlling for pre-decision characteristics), so he does not need to interact market returns.

\subsection{Assumptions}

\subsubsection{Balance and Instrument Relevance}

In terms of instrument balance, Panel B in Table 2 shows that firms considering IPOs are not significantly different between periods of high and low 30-day returns. This goes against the idea that high market returns coincide with a stronger cohort of firms attempting to list in the stock market. Perhaps high long-run returns (e.g., annual returns) coincide with a strong cohort of firms, but short-run returns do not seem to make a difference. Potential differences in the average quality of annual cohorts are captured by calendar time fixed effects in our regression. The absence of differences in pre-IPO variables across samples of short-run returns is consistent with as-random assignment of the instrument Atanasov and Black 2016; Bennedsen, Nielsen, Perez-Gonzalez, and Wolfenzon 2007). It also means that excluding these pre-IPO characteristics, which are also absorbed by the firm fixed effects, 
does not bias the first-stage regression.

As seen in Panel B in Table 2, firms are $7.3 \%$ more likely to complete their IPO when market returns in the previous 30 days are higher than average. That is, when returns are on average $5 \%$ instead of $-3.3 \%$. This difference in completion rates suggests that the instrument is relevant for the IPO decision.

In Table 3 we introduce our definition of compliers, i.e., agents that respond to the instrument as expected. In our setup, compliers are IPOs that are completed after high returns, or IPOs that are withdrawn after low returns. There are 1,869 compliers and 1,598 non-compliers when we split returns into high and low according to the sample mean. We call extreme compliers those firms that complete their IPO after very high returns (above the 25th percentile of the sample distribution), or that withdraw their IPO after very low returns (below the 25th percentile of the sample distribution). Extreme compliers represent $28 \%$ of the sample. In Table 3 we report average pre-IPO characteristics for compliers and non-compliers according to both definitions. We find that compliers are of similar size in terms of assets or sales, and similar profitability and leverage. The absence of significant differences between compliers and non-compliers (see last column) implies that compliers do not represent a subset of the population with special characteristics, and hence it supports the external validity of our results.

Insert Table 3 here

\subsubsection{Exclusion Restriction}

The exclusion restriction implies that 30-day market returns have no effect on future firm outcomes, except through their impact on the IPO decision. All firms in our sample are at the margin of listing. Some firms receive a "nudge" in terms of high (low) market returns and end up listing (withdrawing). Crucially, this nudge needs to have no influence on future outcomes except for its impact on going public.

One challenge to the exclusion restriction is that the instrument may induce the self- 
selection of firms into listed status according to some unobservable measure of quality. Models of asymmetric information, such as Myers and Majluf (1984), predict that strong firms stay out of the market because raising equity is too costly for them. Therefore, withdrawn attempts should represent, on average, better firms than completed IPOs, which would bias the comparison against (instead of in favor) completed IPOs. Firm fixed effects capture unobserved, time-invariant firm quality, but there may still be a residual, time-varying element of quality. Whether 30-day returns, above and beyond year fixed effects and other controls, are enough to cause this sorting of firms is debatable.

The asymmetric information discount is smaller after strong market returns, hence the pool of issuers should be relatively stronger after high returns than after low returns (Lucas and McDonald, 1990). However, changes in the average quality of issuers does not invalidate our tests. The relevant comparison is between the marginal issuer after high returns (the complier after high returns), and the marginal withdrawal after low returns (the complier after low returns). It is precisely firms of similarly strong quality (relative to the average issuer) who decide to issue after high returns and withdraw after low returns. Hence, even in the presence of asymmetric information, it is unclear if there is a bias when making comparisons between compliers as the IV setup does. The very high quality firms that never issue (the "never-takers"), and the very low quality firms that always issue (the "alwaystakers") are not part of these comparisons.12

Another potential violation of the exclusion restriction would be as follows. Imagine that 30-day returns provide a valuable signal of higher expected profitability according to the market. Some firms pick up this signal and complete their IPOs to raise capital. Under this scenario, future profitability is not caused by listed status, but it is only correlated with it.

One immediate doubt about this alternative hypothesis is whether 30-day returns have

\footnotetext{
${ }^{12}$ In terms of several observable characteristics we show in Table A.4 in the appendix that the firms that withdraw after low returns (compliers) are closer to the firms that issue after high returns (also compliers) than firms that withdraw after high returns (the never-takers). Firms that withdraw after high returns are the most profitable, largest in terms of assets, sales, subsidiaries, and the most levered, and hence could be categorized as the strongest. Still, the relevant challenge for our empirical design would be a theory that explains why, after controlling for multiple covariates, there are significant differences between compliers.
} 
predictive power for profitability in two or even three more years, as our tests require. As far as we know, this predictive power has not been documented in the literature. Another way to tackle this alternative hypothesis is to take advantage of the binary nature of the IPO decision. Unless the informational content of returns discontinuously drops at the IPO date, which sounds unlikely, one can expect that returns on the 30 days after the IPO decision also provide a useful signal for long-run profitability. Hence, a placebo test for our identification strategy is to use as instrument the returns immediately after the IPO decision, which cannot influence the IPO decision since it has already been taken. Given that the first stage of the IV setup is severed by construction in this case, then the second stage, which relates future outcomes to the IPO decision, should also be severed. After presenting our main results, we examine this possibility using reduced-form regressions that explore the predictive power of returns at different horizons.

\section{Results}

\subsection{OLS Results}

Before showing results for regression (1), we report a close analog in Figure 3 . We run regressions with separate event-year fixed effects for completed and withdrawn IPOs (firm fixed effects are also included, but industry-year fixed effects are not). In Figure 3 we report these event-year fixed effects $\left(\alpha_{\tau}\right)$ for different dependent variables. The effects on year t-1 are normalized to zero. In Figure 3 Panel A, we see a fall in the ROA of completed IPOs starting with the year of the IPO $(t=0)$, and also going forward. This post-IPO drop in profitability of about 4 percentage points fits with the previous literature on U.S. IPOs (Degeorge and Zeckhauser 1993; Jain and Kini 1994; Mikkelson, Partch, and Shah 1997). A new finding is that withdrawn IPOs see a similar decline in profitability after their IPO attempt. In fact, for $t=0$ and $t=1$ the decline in profitability of completed and withdrawn

IPOs is not statistically different. This suggests that the post-IPO drop in profitability 
is related to selection issues affecting both completed and withdrawn IPOs rather than a causal effect of going public. This is also in line with the conclusion of Spiegel and Tookes (2020) who argue that most IPOs anticipate (not cause) broad negative trends that affect all participants in an industry.

\section{Insert Figure 3 here}

In Figure 3 Panel B, we see a post-IPO increase in the asset growth of completed IPOs. Withdrawn IPOs also increase asset growth after their IPO attempts, but the increase is smaller than in the case of completed IPOs. Panel C showcases similar results for sales ${ }^{13}$

Table 4 shows results for the OLS regression in equation (1). We examine firm ROA, asset growth, $\log$ (sales) and two variables that capture firm scope and commercialization the number of subsidiaries and the number of countries in which a firm operates 14 Firm ROA is not significantly different post IPO, consistent with what we see in Figure 3. Both completed and withdrawn IPOs face a similar decline in profitability after the attempt, so the difference-in-differences $\beta$ coefficient becomes negligible. Instead, we find significant increases for IPO firms in other outcome variables. IPO firms show increases in asset growth, sales, and also an expansion through more subsidiaries and to more countries when compared to withdrawn IPOs. As we noted earlier, these results do not take into account the endogeneity of the IPO decision as firms with better expansion opportunities are more likely to complete their IPO. We now turn to the IV estimation that directly addresses endogeneity.

\section{Insert Table 4 here}

\footnotetext{
${ }^{13}$ Another interesting fact from Figure 3 is that the differences between completed and withdrawn IPOs before their IPO attempts are negligible. To see this look at the coefficients for event year $t=-2$ (since coefficients are normalized to zero in year $t=-1$ ). This evidence supports the parallel trends assumption of the difference-in-differences setup. We do not rely on this assumption for identification since we have an instrument for the IPO decision.

${ }^{14}$ In both cases we use the log of one plus the respective number.
} 


\subsection{First-stage IV Results}

Table 5 presents the first stage results. Columns 1 and 2 show that 30-day returns sharply separate IPO filers into those firms that complete their IPOs versus those that withdraw. If returns over the previous 30 days are positive, then the likelihood of listing increases by $6.9 \%$ (column 2). The first stage is stronger when using the dummy for positive returns, so we use this specification throughout the paper.

\section{Insert Table 5 here}

As seen in the last row of Table 5, the instrument passes the standard threshold of an F-statistic of 10 using the Kleinbergen-Paap test for weak instruments, which is robust to non i.i.d. errors ${ }^{15}$ The F-statistic for the main instrument is 27.84 (see column 2), so the instrument is far from weak. In Table A.3 in the appendix we explore the power of returns at other horizons before the attempt to explain listing decisions (e.g., returns between days -60 and -30 , or between -90 and -60 ). Although statistically significant, these other returns have less power than the returns over the previous 30 days, and present lower F-tests.

Columns 3 and 4 in Table 5 explore the predictive power of market returns of 30 days after the IPO decision. The coefficients are much smaller and statistically insignificant showing that post-IPO returns are not correlated with the decision to complete the IPO. As adjacent returns likely capture similar market signals, but post-IPO returns do not affect the IPO decision as seen in Table 5, they represent a good placebo instrument that we can use to examine the validity of the exclusion restriction.

\subsection{Second-stage IV results}

Table 6] shows the second-stage results. The IPO dummy is positively and significantly related to firm profitability as measured by ROA, and also to our measures of commercial-

\footnotetext{
${ }^{15}$ An alternative F-test for weak instruments is proposed by Montiel-Olea and Pflueger (2013). However, their test is not available for panel IV estimation. To implement their test, we estimate our main regressions using LSDV instead of using a panel fixed-effects model. We find that the Olea-Montiel F-test is nearly identical to the Kleinbergen-Paap test that we report.
} 
ization: number of subsidiaries and the number of countries a firm operates in. We still find positive and large coefficients for asset growth and sales but these coefficients are insignificant given the large standard errors.

Insert Table 6 here

The sharpest difference between the IV and OLS results is for ROA. In the OLS estimation, the coefficient on the IPO dummy was insignificant and close to zero (Table 4). In the IV estimation, the coefficient becomes positive, larger in magnitude, and statistically significant (Table 6). This result suggests that the post-IPO drop in profitability documented in the previous literature is a consequence of endogenous forces rather than a causal effect of going public. With a proper counterfactual (withdrawn IPOs) and as-random variation (given by the instrument), firms that go public appear to increase their profitability rather than decrease it. Isolating the treatment effect of going public provides important new evidence, although it does not imply that selection effects are small or irrelevant. In fact, Maksimovic, Phillips, and Yang (2020) argue that selection effects are at least as large as the treatment effect of going public. We simply argue that the exogenous piece of the variation in listing decisions, i.e., the variation predicted by recent market returns, has a positive impact on profitability. The total effect, once selection and treatment effects are put together, might still be negative.

Our interpretation is that completed IPOs develop a focus on profitability that is not present among still-private firms. In some cases, the so-called "competitive IPOs", this increase in profitability is at the expense of other industry rivals, perhaps those with withdrawn IPO attempts (Hsu, Reed, and Rocholl, 2010). Although still a causal effect, we do not need to affirm that all IPOs have competitive effects on their rivals. It is likely that, in exchange for capital, public investors put pressure on firms to achieve profitability. This pressure seems to benefit firms more than agency costs harm them, at least for the first few years after going public. With the data at hand we cannot rule out negative effects of stock market pressure in the long run (e.g., Stein 1989). 
Higher profitability can be achieved in several ways. One simple way is by increasing sales. While the IV coefficient on sales is large and positive, we do not find statistical significance for the effect (column 3 of Table 6). The large standard errors can reflect that there is an alternative strategy for achieving higher profitability, namely cutting sales of poorly performing products and segments. We provide more precise evidence of commercialization in columns 4 and 5 of Table 6, which shows that completed IPOs expand through new subsidiaries and markets (i.e., neighboring countries). This expansion needs to have strong margins so higher profitability is achieved, ${ }^{16}$

Some examples of IPOs in our sample can illustrate the commercialization interpretation. Gear4music, a UK-based online retailer of musical instruments that went public in 2015, announced in 2017 that the company had recently open new distribution centers in Sweden and Germany. The CEO was quoted as saying: "This has been a transformational year for the business, with further expansion of the Gear4music brand driving record sales and profits." Similarly, Vexim, a French manufacturer of medical equipment that went public in 2012, announced in 2013 the opening of offices in Spain and the UK to serve those new markets.

The magnitude of the IV effect on firm profitability is important. Firms that go public increase ROA by 23 percentage points (column 1 Table 6), or close to one standard deviation of profitability in this sample. For instance, a firm in the 20th percentile of the distribution of profitability would jump to close to the 80th percentile of the distribution in response to going public. The other coefficients in Table 6 are also large, although in line with the large standard deviation of outcomes in small, high-growth firms. For example, asset growth goes up by 93 percentage points (column 3), or close to three-quarters of the standard deviation of asset growth. Similarly, the coefficient in column 4 (5) implies that, starting from the sample mean, firms with completed IPOs add 5.9 (0.25) new subsidiaries (countries), or close

\footnotetext{
${ }^{16}$ The switch towards commercialization can also be achieved through other ways that are not going public. For instance, Gao, Ritter, and Zhu (2013) argue that instead of going public many small firms prefer to be acquired by a large organization to bring their product to market faster and more efficiently than what they can do by growing on a stand-alone basis.
} 
to one half (quarter) of the standard deviation of subsidiaries (countries).

Large IV coefficients relative to OLS coefficients could indicate an IV-blow-up problem, whereby a weak instrument amplifies a potentially small violation of the exclusion restriction. We address this issue from both the econometrics and theory angles following the recommendations of Jiang (2017).

First, from the econometrics perspective, we already showed that our instrument passes standard weak-instruments tests, including those robust to non-i.i.d. errors (see F-statistic in Table 5, Columns 1 and 2). Similarly, our inference is robust to the adjustment of standard errors as a function of first-stage F-statistics proposed by Lee, McCrary, Moreira, and Porter (2021) ${ }^{17}$ Following Young (2021), we check variations in our results when excluding clusters of observations (firms in our case). As seen in Figure A.1 in the appendix, the coefficient and p-values are tightly estimated in the different samples as we exclude clusters, and hence results are not driven by a few outliers. Also following Young (2021), we note that our IV confidence bands reject the OLS point estimate at least for the cases of ROA, the number of subsidiaries, and the number of countries. Finally, as seen in Table A.1 in the appendix, the results in the first and second stages are robust to sample definitions and choice of fixed effects. Overall, the auxiliary tests suggest that our statistical inference is on firm ground.

Second, from the perspective of economic theory, we argue that the magnitude of the IV coefficient is plausible. The first thing to note is the direction of the endogeneity bias in OLS. The expected mean-reversal in profitability proposed by Pástor, Taylor, and Veronesi (2009) should lead to a negative bias in estimating post-IPO profitability. Although not explicitly considered in their model, we can also think that variables such as asset growth and measures of firm scope can be affected by similar mean-reversion dynamics. Hence, from an ex-ante perspective we should not be surprised that IV coefficients are larger than OLS coefficients.

\footnotetext{
${ }^{17}$ Standard errors in our Table 6 have to be multiplied by a factor of 1.008 as implied by the Cragg-Donald Wald $F$-statistic of 97.06 in our first stage (column 2 in Table 5). See Table 3.a in Lee, McCrary, Moreira, and Porter (2021).
} 
Also from the theory perspective, it is worth noting that a change in strategy - from exploration to commercialization - can result in a one-time large change in performance and firm scope like the one we document. A jump in profitability is likely to be needed in equilibrium to compensate for the large costs involved in going public. For example, Gahng, Ritter, and Zhang (2021) show that the costs of the median IPO are close to $5 \%$ of market capitalization (e.g., underwriter commissions, underpricing, etc.). Save for exceptions, going public happens only once in a firm's life cycle, so it is not unreasonable to think that it can change the course of a firm's history in a dramatic way.

Besides the magnitude of coefficients, other usual caveats of IV estimations apply here. The IV approach identifies the effects of going public by focusing on the sub-population of filers whose IPO decision is affected by prior market returns. This local average treatment effect (LATE) may not coincide with the average treatment effect (ATE) in the population. In our case, compliers can be understood as firms who were previously at the "margin" of completing their IPO before they were nudged by market returns to complete or withdraw. As we show in Table 3 , compliers do not seem to be a set of firms with special characteristics, so our results likely apply to the average firm going public as well.

\subsection{Reduced Form and Placebo}

Table 7 shows results of the regression of firm outcomes directly on short-term market returns. The coefficients represent the reduced-form or intent-to-treat effect. Panel A shows the results where the dependent variables are run against the main instrument (Positive 30day ret $X$ Post). The results in Panel A are in principle consistent with the exclusion restriction holding, as the coefficient from the reduced-form regression is approximately the coefficient from the first-stage regression times the coefficient from the second-stage regression (Atanasov and Black, 2016). For instance, the reduced-form coefficient for ROA in Column 1 is $1.6 \%$, which is approximately $6.9 \%$ (first stage) times $23.3 \%$ (second stage). If there was an additional direct effect from short-term returns on long-term profitability, 
the reduced-form coefficient could have been significantly different (e.g., in the hypothetical case that after strong returns firms receive a long-term benefit such as perpetually lower cost of capital). Although consistent with as-random assignment, the fact that the coefficient on the reduced-form regression is well-behaved is merely suggestive.

Insert Table 7 here

More compelling evidence on the validity of the exclusion is presented in Panel B of Table 7. The results show that the placebo instrument (Positive 30-day fwd X Post) has no bearing on post-IPO outcomes in reduced-form regressions. Given that, as market signals, the returns just after the IPO are close substitutes to returns pre-IPO, the lack of a reducedform effect suggests that pre-IPO market returns are not simply signals, but have an effect through some other channel (the decision to list). The signalling hypothesis would need to explain why the informational content of returns drop discontinuously at the date of the IPO so the effects vanish in less than 30 days. Overall, the results speak in favor of the exclusion restriction since, when market returns are uncorrelated to the IPO decision (columns 3 and 4 of Table 5), there are no effects on profitability or other firm-level outcomes either (Panel $\mathrm{B}$ in Table 7).

\subsection{Cross-sectional Variation and Mechanisms}

We now examine heterogeneity of our results through industry- and country-level variation to understand why going public affects firms. We study three prominent mechanisms: financial constraints, agency problems, and information provision. Adding an interaction term between the endogenous IPO decision and a time-invariant characteristic requires estimating two first stages: One for the IPO dummy and one for the interaction term. The standard approach is to use as additional instrument the interaction of the cross-sectional characteristic with the time-varying instrument (Positive 30-day ret $x$ Post). We present the extended first-stages in Table A.5 of the Appendix. 


\subsubsection{Financial Constraints}

One of the advantages of going public is to improve a firm's access to capital. For example, Brav (2009) concludes that private equity is more costly than public equity when examining private and public companies in the U.K. If this is the case, then the benefits of going public should be more prevalent among firms that demand more capital from outside investors. In order to take this prediction to the data we measure the need for outside capital with the financial dependence index of Rajan and Zingales (1998). This variable captures the natural or technological reliance of different industries on external capital, i.e., capital beyond internally generated cash flows.

For the regressions in Table 8 we interact the IPO dummy with a dummy for high financial dependence. High financial dependence equals 1 if the firm operates in a 3-digit SIC industry with financial dependence above the sample mean, and 0 otherwise.

Insert Table 8 here

The results in Table 8 shows that the impact of going public on ROA and asset growth is stronger in industries with high financial dependence. For instance, firms in high dependence industry see their ROAs increase by 5.6 percentage points more than other firms (column 1), and asset growth increases by 25 percentage points more (column 2). In line with the presence of financial constraints, going public leads firms that rely more on external capital to increase profitability and investment beyond what is seen in other firms that go public.

Table 8 also illustrates the different growth paths taken by high- and low-dependence firms. High-dependence firms show a smaller effect in the number of subsidiaries and countries than low-dependence firms. This is reflected in the negative interactions of the IPO dummy with high financial dependence in columns 4 and 5 of Table 8 . Hence, when a firm in a high-dependence industry gets fresh capital it adds more assets, but in relatively fewer subsidiaries and countries than a firm in a low-dependence industry. Since firms in high-dependence industries are more likely to be constrained before the IPO than firms in 
low-dependence industries, it is plausible that they have more room to grow organically without stepping outside their current market segments.

The industry-level financial dependence is arguably more exogenous to the firm-level decision of going public than other traditional indicators of financial constraints such as leverage, firm size, or age (Hadlock and Pierce, 2010). We still report the heterogeneity of our results using these other proxies of financial constraints in Table A.6 in the appendix.

\subsubsection{Agency Problems}

A disadvantage of going public is the dispersion of ownership, which results in weaker incentives for owner-managers (Jensen and Meckling, 1976). Owner-managers are more tempted to consume private benefits, or take actions that do not increase the market value of the firm. If agency is a serious concern, then the benefits of going public should be stronger when minority investors are better protected by laws and regulations. Investors will be less worried about insiders extracting rents from them if they are well protected, and thus they will be more willing to provide capital.

We study whether the effects of going public vary according to measures of investor protection at the country level. We use the anti-self-dealing index from Djankov, La Porta, López-de-Silanes, and Shleifer (2008), which reflects how difficult it is for corporate insiders to get away with the diversion of firm resources and opportunities. In Table 9 we interact the IPO dummy with an indicator variable that takes a value of 1 if the firm operates in a country with investor protection above the sample mean, and 0 otherwise.

\section{Include Table 9 here}

Inspection of the results in Table 9 reveals that there is an additional positive impact on ROA, asset growth, and the number of subsidiaries in countries with high investor protection. These results are consistent with investors being more willing to provide capital if firms are less likely to be subject to agency problems. Overall, firms need an environment of strong investor protection to fully realize the benefits of going public. 


\subsubsection{Information}

The information reflected in stock prices can help investors to monitor the firm and incentivize managers (Holmstrom and Tirole 1993; Edmans 2009). Also, if more and better information is disclosed, then investors will be more willing to provide capital as they can better ascertain the underlying value of the firm. We capture cross-country variation in disclosure with an index for disclosure requirements in the IPO prospectus (La Porta, López-de-Silanes, and Shleifer, 2006). The indicator for high disclosure requirement equals one if the firm operates in a country with disclosure requirements above the sample mean, and 0 otherwise. As before, we interact the IPO dummy with the cross-country indicator. We present the results in Table 10 .

\section{Include Table 10 here}

The results in Table 10 show an incremental positive effect of high disclosure on ROA. The effect is of similar magnitude as with high investor protection (2.5 percentage points). In practice investor protection and disclosure are positively correlated. Hence, whether the incremental effect in profitability can be attributed to better investor protection or to better disclosure is not entirely clear. The key takeaway from Tables 9 and 10 is that the positive effects of the IPO are stronger when there is a more investor-friendly environment 18

\subsection{Long-term Outcomes}

\subsubsection{Patents}

We now explore the impact of going public on long-term patenting activity. We focus only on the post-IPO number of (eventually granted) patent applications, since we do not have data on patent citations like Bernstein (2015) has for U.S. firms. We use forward-looking

\footnotetext{
${ }^{18}$ In Tables A.7 and A.8 in the appendix we study the combined effects of industry-level and countrylevel measures to further assess the interaction of each of these channels on IPOs. As investor protection and disclosure are highly correlated, we present the interaction effects of financial dependence with investor protection and disclosure separately. Overall, the effects of investor protection at the country level seem to dominate those of financial dependence at the industry-level, at least for ROA and asset growth.
} 
moving averages for patents to account for delays in the formal process of granting patents. We examine the impact of the IPO decision by itself and also interacted it with industry and country variables.

Using the IV setup we find a negative impact of going public on patent applications on average (column 1 in Table 11 shows), which is similar to Bernstein (2015). However, this average effect is not statistically significant. IPO firms in financially dependent industries have more patents that IPO firms in other industries (column 2). Although the effect of financial dependence is in line with the results in Acharya and Xu (2016), and Brown, Fazzari, and Petersen (2009), it is economically very small and not statistically significant.

We find a stronger and significant negative effect on patents for IPOs in countries with high anti-self-dealing and high disclosure requirements (columns 3 and 4 in Table 11). Overall, in markets that resemble the U.S. (Bernstein's sample) in terms of investor friendliness, we find that the number of patents declines after going public. The negative effect of disclosure on the innovation of newly listed firms is also consistent with the results in Dambra and Gustafson (2021) who study variation in disclosure rules across U.S. firms.

\section{Insert Table 11 here}

The negative impact on innovation, combined with the positive impact on profitability and asset growth, suggests that there is a shift in strategy from exploration and searching for new ideas to commercialization. Private firms provide strong incentives to discover patentable ideas. When firms enter public markets, they move along the life cycle towards commercialization and a focus on higher margins.

\subsubsection{M\&A activity}

We also examine whether the IPO firm engages in acquisitions or becomes the target of an acquisition after the IPO. We present the results using our instrumental variables approach in Tables A.9 and Table A.10 of the appendix. We do not find significant results for acquisition 
activity in contrast to Arikan and Stulz (2016) who find that recent IPO firms make many acquisitions (although relative to older public firms, not relative to withdrawn IPOs). We find that IPO firms in high financial dependence industries make fewer acquisitions, which is consistent with our previous result in Table 8 that firms in high dependence industries grow more organically. We do not find that IPO firms are significantly more likely to be the targets of acquisitions than withdrawn IPOs.

\subsection{Going Public or Capital Raising?}

Going public provides a capital infusion. In this final section we explore whether IPOs differ from other instances of capital raising. We address this issue in three complementary ways. First, in our sample of completed and withdrawn IPOs we study debt growth and equity raising other than through the IPO. It could be the case that withdrawn IPOs simply substitute debt or private equity for public equity. Second, we study corporate governance outcomes for completed and withdrawn firms. Finally, we study profitability around seasoned equity offerings (SEOs) during this sample period in Europe.

From the balance sheet data we identify years in which debt or shareholders' net funds (i.e., paid capital) increase by more than 100\%. This captures instances of capital raising that are comparable to IPOs. For example, shareholders' funds increase by a factor of 4 on average in the IPO year.

In Table 12, we run our main IV specification with dummies for the years of large increases in shareholders' funds and debt as dependent variables. Crucially, we exclude the IPO year in these regressions. In column 1 we find a small and insignificant coefficient on the IPO dummy, meaning that, outside the IPO itself, there is no relevant difference in capital increases between completed and withdrawn IPOs. This is consistent with the idea that public equity is cheaper than private equity, and therefore not easily substitutable in withdrawn firms (Brav, 2009). If we do the same with debt growth (column 2) we find a negative and highly significant coefficient on the IPO dummy. This suggests that withdrawn IPOs raise more 
debt to partly compensate for the lack of equity financing.

\section{Insert Table 12 here}

In columns 3 and 4 of Table 12 we study the frequency of changes in CEO and CFO. We find that it is $14.9 \%(5.6 \%)$ more likely to see a change in CEO (CFO) in completed than in withdrawn IPOs. Hence, going public has an impact on corporate governance, as reflected by turnover in key executive positions. Arm's-length capital would not have these effects.

Finally, we study profitability around other events of capital raising, in particular SEOs. Butler, Fauver, and Sypiridopoulos (2019) consider SEOs as a sort of placebo for IPOs in order to disentangle capital raising from other mechanisms. The study of SEOs is also

motivated by Loughran and Ritter (1997) who show that there is a drop in profitability after SEOs similar to the drop after IPOs. In Figure 4 we show the ROA of 500 European SEO firms and matched firms in this sample period. The match is based on country, year, size, and profitability the year before the SEO. We find a slight decline in profitability of around one percentage point two years after the SEO. There is a similar decline in the profitability of the firms in the matched sample. Overall, the drop in profitability applies more to IPOs than to SEOs, and hence it does not seem to be a feature of all capital-raising activities. The impact of going public goes above and beyond simply raising capital.

\section{Insert Figure 4 here}

\section{Conclusions}

This paper sheds light on the consequences of going public using a large sample of close to 3,400 firms that file for an initial public offering in 16 European countries over 1997-2017. Our data contains pre- and post-filing financial information irrespective of whether firms complete their IPO or not (i.e., for completed and withdrawn IPOs). The panel structure of our data allows us to control for a host of self-selection issues and life-cycle patterns. 
We directly address the endogeneity of IPO completion following the strategy in Bernstein (2015). We instrument for IPO completion using short-term market returns before the IPO decision. Market returns in this short window can affect the decision to complete the IPO, but are unlikely to directly affect long-run outcomes.

Consistent with prior finding in the literature, we show that firms profitability goes down after the IPO. However, we also show that the profitability of withdrawn-IPO firms also goes down after the IPO, so the OLS differences-in-differences effect on firm performance is essentially zero. After correcting for endogeneity, we find a strong a positive effect on performance. Using a proper counterfactual and tackling the endogeneity problem, we find a benefit of increased profitability for firms that go public - a result that is the opposite of the prior literature.

We also show that firms expand their operations to more countries and operate more subsidiaries post-IPO - consistent with increased commercialization. Exploiting cross-sectional variation across industries and countries, we find that the effects on profitability and performance are stronger in financially dependent industries and in investor-friendly countries. However, patenting activity goes down in those environments - suggesting a switch in firm strategy from exploration and innovation towards commercialization.

Our findings support the proposition that firms benefit by going public despite potentially higher agency problems after the IPO. Becoming publicly traded provides financial capital to firms that helps them commercialize their products. Investors likely push for profitability in exchange for their capital and firms deliver in the years subsequent to the IPO by changing their strategy from innovation to commercialization. 


\section{References}

Acharya, Viral, and Zhaoxia Xu, 2016, Financial dependence and innovation: The case of public versus private firms, Journal of Financial Economics 124, 223-243.

Arikan, Asli, and Rene M. Stulz, 2016, Corporate acquisitions, diversification, and the firm's life-cycle, Journal of Finance 71, 139-193.

Asker, John, Joan Farre-Mensa, and Alexander Ljungqvist, 2015, Corporate investment and stock market listing: A puzzle?, Review of Financial Studies 28, 342-390.

Atanasov, Vladimir, and Bernard Black, 2016, Shock-based causal inference in corporate finance and accounting research, Critical Finance Review 5, 207-304.

Babina, Tania, Paige Ouimet, and Rebecca Zarutskie, 2020, IPOs, human capital, and labor reallocation, Columbia University and University North Carolina Chapel Hill Working Paper.

Bennedsen, Morten, Kasper Meiner Nielsen, Francisco Perez-Gonzalez, and Daniel Wolfenzon, 2007, Inside the family firm: The role of families in succession decisions and performance, Quarterly Journal of Economics 122, 647-691.

Bernstein, Shai, 2015, Does going public affect innovation?, Journal of Finance 70, 1365-1403.

Borisnov, Alexander, Andre Ellul, and Merih Sevilir, 2019, Access to public capital markets and employment growth, University of Cincinnati and University of Indiana Working Paper.

Brav, Omer, 2009, Access to capital, financial structure, and the funding of the firm, Journal of Finance 64, 263-308.

Brown, James, Steven Fazzari, and Bruce Petersen, 2009, Financing innovation and growth: Cash flow, external equity, and the 1990s R\&D boom, Journal of Finance 64, 151-185.

Busaba, Walid, Lawrence Benveniste, and Re-Jin Guo, 2001, The option to withdraw IPOs during the premarket: Empirical analysis, Journal of Financial Economics 60, 73-102.

Butler, Alexander, Larry Fauver, and Ioannis Sypiridopoulos, 2019, Local economic spillover effects of stock market listings, Journal of Financial and Quantitative Analysis 54, 1025-1050.

Cornaggia, Jess, Mathew Gustafson, Jason Kotter, and Kevin Pisciotta, 2020, Initial public offerings and the local economy, Penn State University Working Paper.

Cornelli, Francesca, David Goldreich, and Alexander Ljungqvist, 2006, Investor sentiment and pre-IPO markets, Journal of Finance 61, 1187-1216.

Dambra, Michael, and Matthew Gustafson, 2021, Do the burdens to being public affect the the investment and innovation of newly public firms?, Management Science 57, 594-616.

— , and Kevin Pisciotta, 2021, What is the effect of an additional dollar of IPO proceeds?, Journal of Corporate Finance $66,-$.

Degeorge, Francois, and Richard Zeckhauser, 1993, The reverse LBO decision and firm performance: Theory and evidence, Journal of Finance 48, 1323-1348.

Derrien, Francois, 2005, IPO pricing in "hot" market conditions: Who leaves money on the table?, Journal of Finance 60, 487-521.

Djankov, Simeon, Rafael La Porta, Florencio López-de-Silanes, and Andrei Shleifer, 2008, The law and economics of self-dealing, Journal of Financial Economics 88, 430-465. 
Doidge, Craig, Andrew Karolyi, and Rene Stulz, 2013, The U.S. left behind? Financial globalization and the rise of IPOs outside the U.S., Journal of Financial Economics 110, 546-573.

Edelen, Roger, and Gregory Kadlec, 2005, Issuer surplus and the partial adjustment of IPO prices to public information, Journal of Financial Economics 77, 347-373.

Edmans, Alex, 2009, Blockholder trading, market efficiency, and managerial myopia, Journal of Finance 64, $2481-2513$.

Gahng, Minmo, Jay Ritter, and Donghang Zhang, 2021, SPACs, Working Paper pp. - .

Gao, Xiaohui, Jay Ritter, and Zhongyan Zhu, 2013, Where have all the IPOs gone?, Journal of Financial and Quantitative Analysis 48, 1663-1692.

Gilje, Erik, and Jerome Taillard, 2016, Do private firms invest differently than public firms? Taking cues from the natural gas industry, Journal of Finance 71, 1733-1778.

Hadlock, Charles, and Joshua Pierce, 2010, New evidence on measuring financial constraints: Moving beyond the KZ index, Review of Financial Studies 23, 1909-1940.

Helbing, Pia, Brian Lucey, and Samuel Vigne, 2019, The determinants of IPO withdrawal - Evidence from Europe, Journal of Corporate Finance 56, 415-436.

Holmstrom, Bengt, and Jean Tirole, 1993, Market liquidity and performance monitoring, Journal of Political Economy 101, 678-709.

Hsu, Hung-Chia, Adam Reed, and Jorg Rocholl, 2010, The new game in town: Competitive effects of IPOs, Journal of Finance 65, 495-528.

Jain, Bharat, and Omesh Kini, 1994, The post-issue operating performance of IPO firms, Journal of Finance 49, 1699-1726.

Jensen, Michael, and William Meckling, 1976, Theory of the firm: Managerial behavior, agency costs and ownership structure, Journal of Financial Economics 3, 305-360.

Jiang, Wei, 2017, Have instrumental variables brought us closer to truth?, Review of Corporate Finance Studies 6, 127-140.

Kahle, Kathleen, and Rene Stulz, 2017, Is the U.S. public corporation in trouble?, Journal of Economic Perspectives 31, 67-88.

Kim, Woojin, and Michael Weisbach, 2008, Motivations for public equity offers: An international perspective, Journal of Financial Economics 87, 281-307.

La Porta, Rafael, Florencio López-de-Silanes, and Andrei Shleifer, 2006, What works in securities laws?, Journal of Finance 61, 1-32.

Lee, David, Justin McCrary, Marcelo Moreira, and Jack Porter, 2021, Valid T-ratio inference for IV, NBER Working Paper 29124 pp. -.

Loughran, Tim, and Jay Ritter, 1997, The operating performance of firms conducting seasoned equity offerings, Journal of Finance 52, 1823-1850.

— 2002, Why don't issuers get upset about leaving money on the table in IPOs?, Review of Financial Studies 15, 413-433.

Lucas, Deborah, and Robert McDonald, 1990, Equity issues and stock price dynamics, Journal of Finance 45, 1019-1043. 
Maksimovic, Vojislav, Gordon Phillips, and Liu Yang, 2020, Are public firms really myopic? Evidence from matching IPO firms at birth, University of Maryland and Dartmouth College Working Paper.

Mikkelson, Wayne H., M. Megan Partch, and Kshitij Shah, 1997, Ownership and operating performance of companies that go public, Journal of Financial Economics 44, 281-307.

Montiel-Olea, Jose, and Carolin Pflueger, 2013, A robust test for weak instruments, Journal of Business 83 Economic Statistics 31, 358-369.

Myers, Stewart, and Nicholas Majluf, 1984, Corporate financing and investment decisions when firms have information that investors do not have, Journal of Financial Economics 13, 187-221.

Pagano, Marco, Fabio Panetta, and Luigi Zingales, 1998, Why do companies go public? An empirical analysis, Journal of Finance 53, 27-64.

Pástor, Luboš, Lucian Taylor, and Pietro Veronesi, 2009, Entrepreneurial learning, the IPO decision, and the post-IPO drop in firm profitability, Review of Financial Studies 22, 3000-3046.

Phillips, Gordon M., and Giorgo Sertsios, 2017, Financing and new product decisions of private and publicly traded firms, Review of Financial Studies 30, 1744-1789.

Rajan, Raghuram, and Luigi Zingales, 1998, Financial dependence and growth, American Economic Review $88,559-586$.

Spiegel, Matthew, and Heather Tookes, 2020, Why does an IPO impact rival firms?, Review of Financial Studies 33, 3205-3249.

Stein, Jeremy, 1989, Efficient capital markets, inefficient firms: A model of myopic corporate behavior, Quarterly Journal of Economics 104, 655-669.

Teoh, Siew-Hong, Ivo Welch, and T.J. Wong, 1998, Earnings management and the long-run market performance of initial public offerings, Journal of Finance 53, 1935-1974.

Young, Alwyn, 2021, Consistency without inference: Instrumental variables in practical application, Working Paper pp. - . 
Figure 1: IPOs over Countries and Years

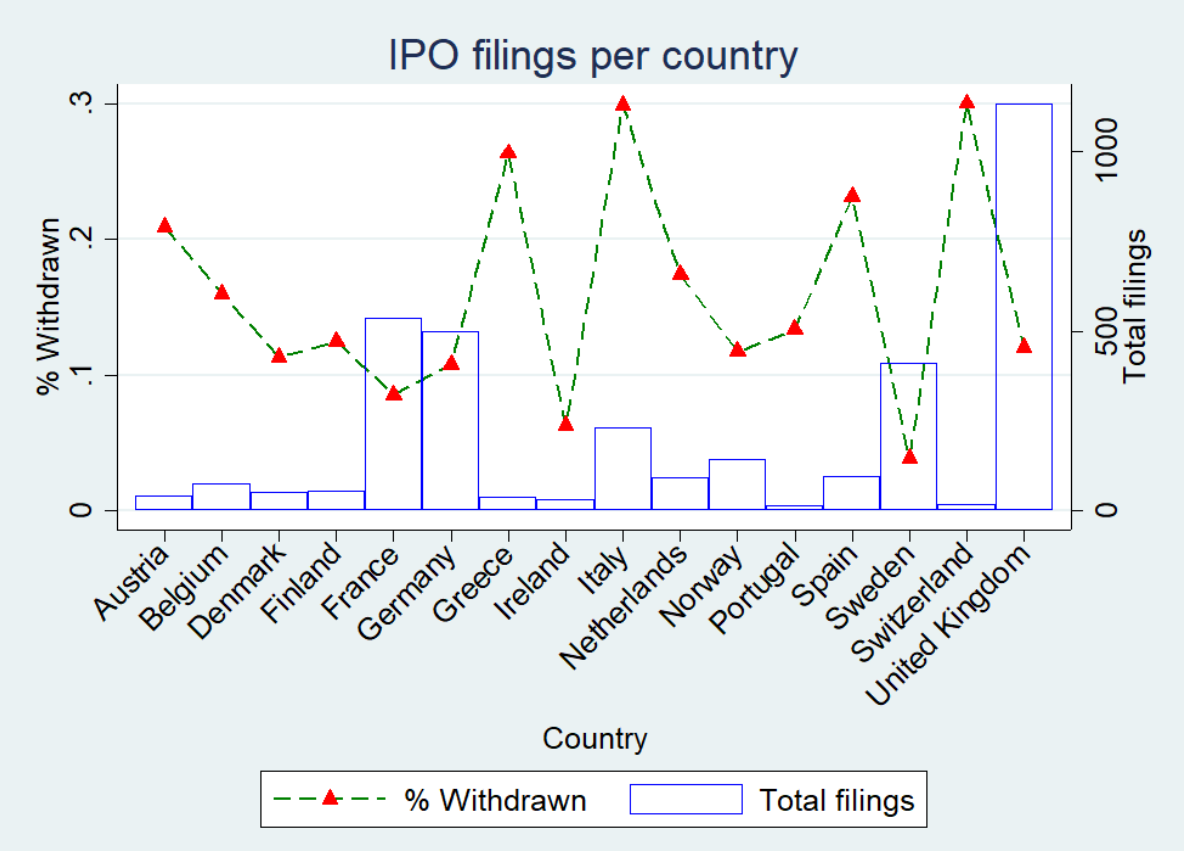

(a)

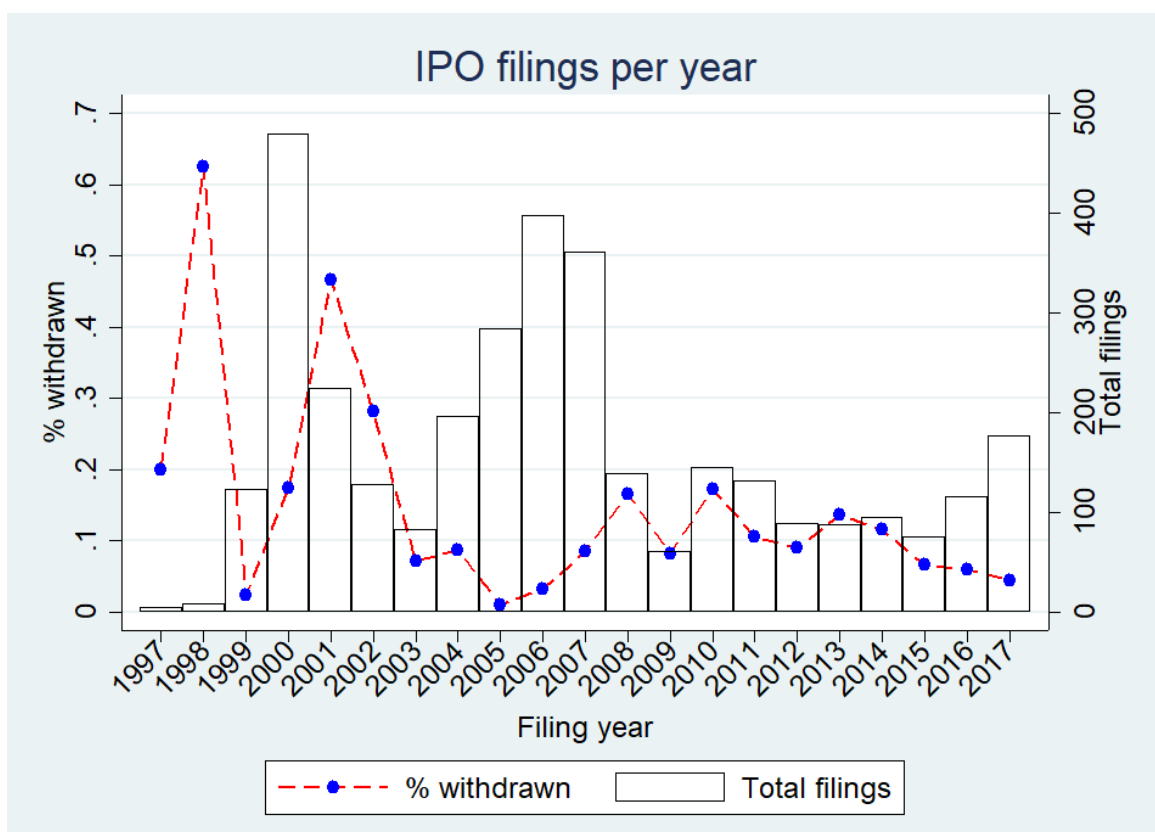

(b)

Notes: This figure shows the total number of IPO filings and the fraction of withdrawn IPOs by country of listing (panel a) and year (panel b). 
Figure 2: Observations by Event Year

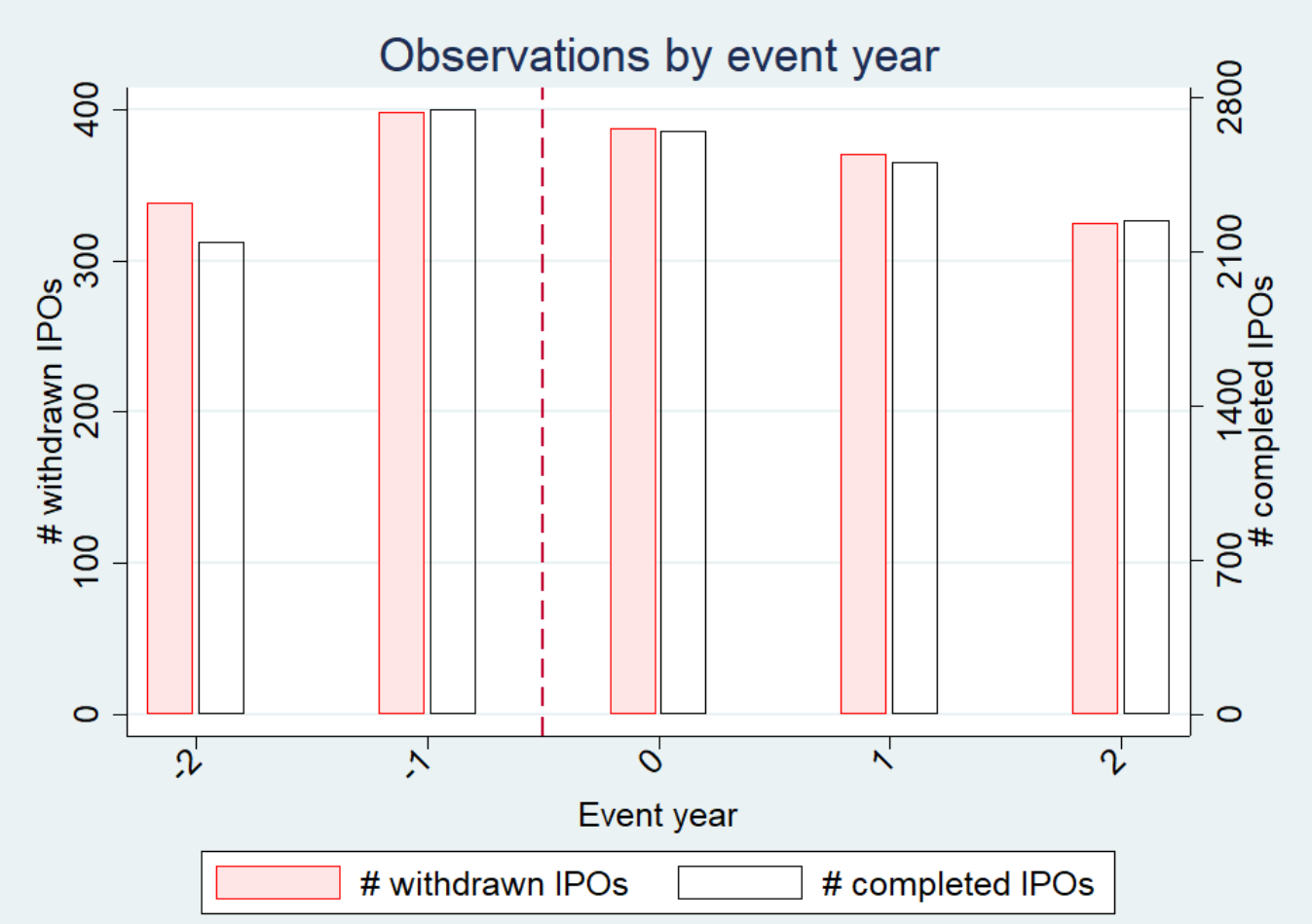

Notes: The figure shows the number of observations per event-year for withdrawn IPOs (dark bar, left axis) and completed IPOs (light bar, right axis). Event years are measured at the end-ofthe-year around the IPO-attempt year $(\mathrm{t}=0)$. 
Figure 3: Firm Outcomes by Event Year for Completed and Withdrawn IPOs

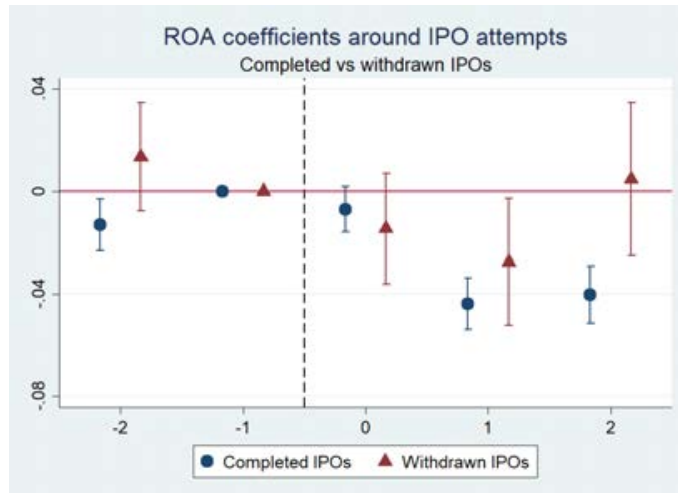

(a)

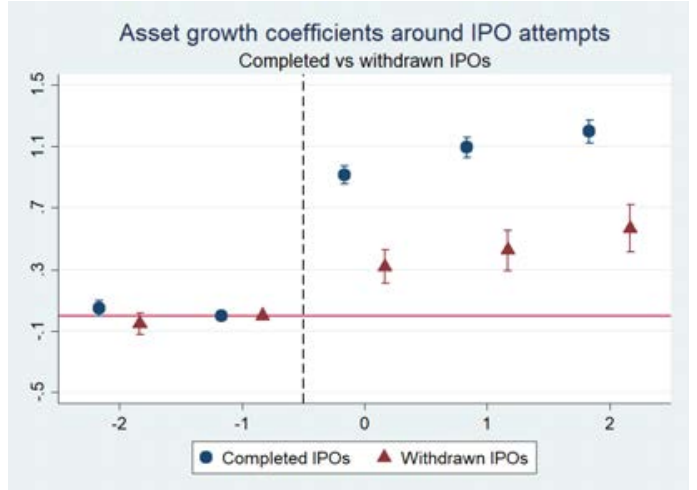

(b)

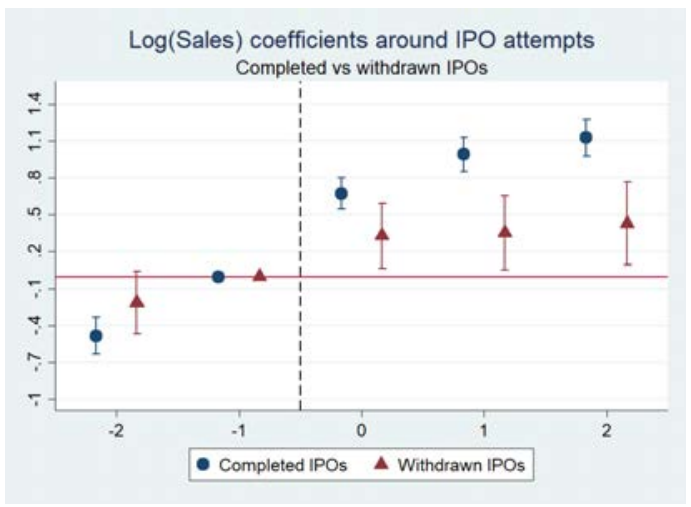

(c)

Notes: The figures displays coefficient estimates of event-time fixed effects. The dependent variable is run against event-time fixed effects for completed and withdrawn IPOs, setting $t=-1$ as the default category. The regressions include firm fixed effects to account for within-firm dynamics. 
Figure 4: SEOs

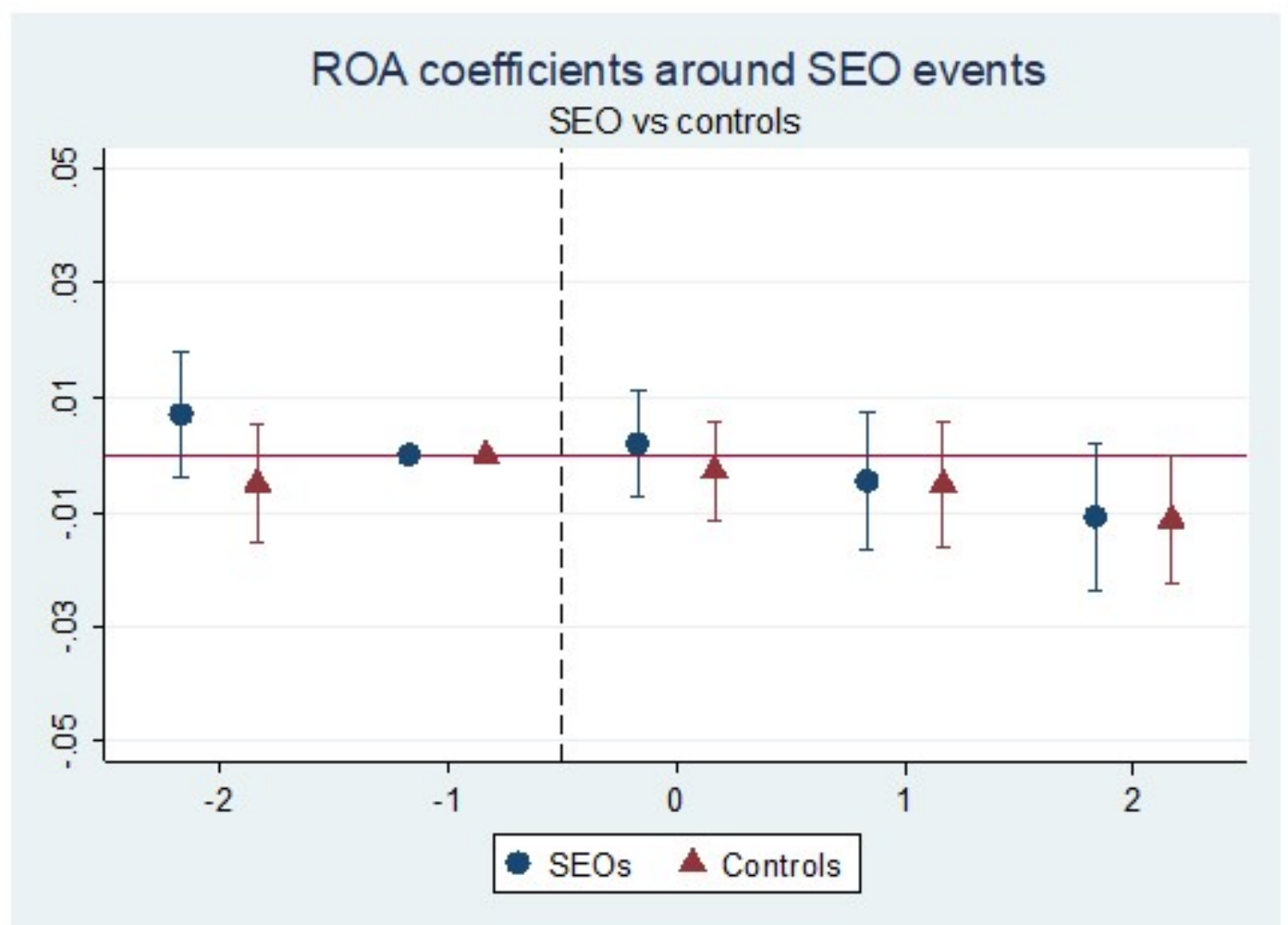

Notes: The figures displays coefficient estimates of event-time fixed effects for ROA in a sample of SEO firms and matched control firms based on country, year, size, and profitability the year before the SEO. ROA is run against event-time fixed effects setting $t=-1$ as the default category. The regressions include firm fixed effects to account for within-firm dynamics. 
Table 1: Summary Statistics

This table shows the summary statistics of the variables. Completed IPO is an indicator variable that takes a value of 1 if a firm completed an IPO and 0 otherwise. Post is an indicator variable that takes a value of 1 for the IPO-attempt year and after; 0 otherwise. $\mathrm{IPO}=$ Completed IPO $\mathrm{x}$ Post. ROA is EBITDA over book assets. Assets (MM) is book assets in 2019 millions of Euros. Asset growth is Log(assets) (t)- $\log$ (assets) (t-1). Leverage is the sum of total liabilities divided by the book value of assets. Sales (MM) is yearly sales in 2019 millions of Euros. Countries is the number of countries where a firm operates in a year. Subsidiaries is the number of subsidiaries a firm owns in a year. Age is calendar year minus incorporation year. Returns 30 days is the market return (country-index) where the firm is listed, for the month preceding the IPO listing, or withdrawn month. Positive 30-day ret is an indicator variable that takes a value of 1 if Returns 30 days is positive, and 0 otherwise. Accounting variables are winsorized at the $0.5 \%$ level. All log variables are the log of one plus the variable of interest.

\begin{tabular}{lrrrrrrrr}
\hline & Mean & P10 & P25 & \multicolumn{1}{c}{ P50 } & P75 & P90 & SD & Total \\
\hline Completed IPO & 0.87 & 0.00 & 1.00 & 1.00 & 1.00 & 1.00 & 0.34 & 14,410 \\
Post & 0.60 & 0.00 & 0.00 & 1.00 & 1.00 & 1.00 & 0.49 & 14,410 \\
IPO & 0.52 & 0.00 & 0.00 & 1.00 & 1.00 & 1.00 & 0.50 & 14,410 \\
ROA & -0.02 & -0.35 & -0.09 & 0.03 & 0.10 & 0.19 & 0.24 & 12,321 \\
Assets (MM) & 172.77 & 0.48 & 2.34 & 10.60 & 55.21 & 333.48 & 598.43 & 13,696 \\
Asset growth & 0.59 & -0.21 & 0.00 & 0.09 & 0.82 & 1.85 & 1.25 & 12,180 \\
Leverage & 0.49 & 0.08 & 0.25 & 0.51 & 0.72 & 0.86 & 0.28 & 12,674 \\
Sales (MM) & 318.67 & 0.45 & 3.73 & 20.27 & 113.76 & 640.92 & $1,085.94$ & 12,332 \\
Subsidiaries & 3.24 & 0.00 & 0.00 & 0.00 & 2.00 & 7.00 & 11.30 & 14,110 \\
Countries & 1.22 & 1.00 & 1.00 & 1.00 & 1.00 & 1.00 & 0.93 & 14,110 \\
Age & 11.31 & 1.00 & 3.00 & 7.00 & 13.00 & 24.00 & 15.22 & 12,883 \\
Returns 30 days & 0.01 & -0.06 & -0.02 & 0.01 & 0.04 & 0.07 & 0.06 & 14,110 \\
Positive 30-day ret & 0.62 & 0.00 & 0.00 & 1.00 & 1.00 & 1.00 & 0.49 & 14,110 \\
\hline
\end{tabular}


Table 2: Sorts by IPO status and returns

This table shows averages of the main variables for sample splits before the IPO attempt. Panel A presents the means and differences according to IPO status (treatment): withdrawn vs. completed IPOs Panel B shows the means and differences according to pre-attempt market returns above or below the sample mean (exposure to the instrument). Significant at: $* 10 \%, * * 5 \%$ and $* * * 1 \%$.

\begin{tabular}{lrrr}
\hline & \multicolumn{3}{c}{ Panel A: Split by endogenous treatment } \\
\cline { 2 - 4 } Variable (pre IPO attempt) & Withdrawn & Completed IPO & \multicolumn{1}{c}{ Diff. } \\
\hline ROA & 0.013 & -0.015 & $-0.028^{* *}$ \\
Assets (MM) & 251.93 & 135.69 & $-116.24^{* * *}$ \\
Asset growth & -0.043 & -0.029 & -0.014 \\
Leverage & 0.571 & 0.541 & $-0.030^{*}$ \\
Sales (MM) & 540.56 & 255.15 & $-285.41^{* * *}$ \\
Subsidiaries & 1.655 & 1.382 & -0.273 \\
Countries & 1.156 & 1.081 & $-0.065^{* *}$ \\
Returns 30 days & -0.009 & 0.011 & $0.020^{* * *}$ \\
Positive 30-day ret & 0.428 & 0.645 & $0.217^{* * *}$ \\
\# of firms & 430 & 3,037 & \\
\hline
\end{tabular}

Panel B: Split by the instrument

\begin{tabular}{lrrr} 
Variable (pre IPO attempt) & Low ret. & High ret & Diff. \\
\hline ROA & -0.005 & -0.018 & -0.012 \\
Assets (MM) & 152.72 & 143.30 & -6.42 \\
Asset growth & -0.036 & -0.025 & 0.011 \\
Leverage & 0.547 & 0.542 & -0.005 \\
Sales (MM) & 296.42 & 284.99 & -11.42 \\
Subsidiaries & 1.337 & 1.495 & 0.158 \\
Countries & 1.086 & 1.111 & 0.025 \\
Returns 30 days & -0.033 & 0.050 & $0.083^{* * *}$ \\
Completed IPO & 0.840 & 0.912 & $0.073^{* * *}$ \\
\# of firms & 1,734 & 1,735 & \\
\hline
\end{tabular}


Table 3: Completed and Withdrawn IPOs for Complier and Non-complier Firms: Summary Statistics

The table shows averages of the main variables before the IPO attempt for Compliers (Completed IPO after high returns + Withdrawn IPOs after low returns) and Non-compliers (Withdrawn IPO after high returns + Completed IPOs after low returns). In Panel A, high (low) returns are those above (below) the sample mean, while in Panel B, high (low) returns are those above (below) the 25 th percentile in the sample. Significant at: ${ }^{*} 10 \%, * * 5 \%$ and $* * * 1 \%$.

\begin{tabular}{lrrr}
\hline & \multicolumn{3}{c}{ Panel A: All Compliers } \\
\hline Variable (pre IPO attempt) & Compliers (C) & Non-compliers (NC) & Diff: C-NC \\
\hline ROA & -0.017 & 0 & -0.011 \\
Assets (MM) & 149.29 & 149.67 & 0.38 \\
Asset growth & -0.028 & -0.035 & 0.007 \\
Leverage & 0.54 & 0.55 & -0.011 \\
Sales (MM) & 293.07 & 287.97 & 5.10 \\
Subsidiaries & 1.42 & 1.41 & 0.01 \\
Countries & 1.1 & 1.1 & 0.00 \\
\# of firms & 1,869 & 1,598 & \\
\hline & Panel B: Extreme Compliers & \\
\hline Variable (pre IPO attempt) & Compliers (C) & Non-compliers $(\mathrm{NC})$ & Diff: \\
\hline ROA & -0.009 & -0.013 & 0.004 \\
Assets (MM) & 140.76 & 152.84 & -12.08 \\
Asset growth & -0.021 & -0.034 & 0.013 \\
Leverage & 0.549 & 0.543 & 0.006 \\
Sales (MM) & 271.26 & 298.41 & -27.16 \\
Subsidiaries & 1.531 & 1.371 & 0.160 \\
Countries & 1.114 & 1.093 & 0.021 \\
\# of firms & 976 & 2,491 & \\
\hline
\end{tabular}


This table shows OLS regressions. All log variables are the log of one plus the variable of interest. Standard errors (in parentheses) are adjusted for heteroscedasticity and clustered at the firm level. Significant at: ${ }^{*} 10 \%, * * 5 \%$ and $* * * 1 \%$.

\begin{tabular}{|c|c|c|c|c|c|}
\hline VARIABLES & $\begin{array}{c}(1) \\
\mathrm{ROA}\end{array}$ & $\begin{array}{c}(2) \\
\text { Asset growth }\end{array}$ & $\begin{array}{c}(3) \\
\log (\text { Sales })\end{array}$ & $\begin{array}{c}(4) \\
\log (\text { Subs. })\end{array}$ & $\begin{array}{c}(5) \\
\log (\text { Countries })\end{array}$ \\
\hline IPO & $\begin{array}{l}-0.002 \\
(0.010)\end{array}$ & $\begin{array}{c}0.515^{* * *} \\
(0.064)\end{array}$ & $\begin{array}{c}0.626^{* * *} \\
(0.128)\end{array}$ & $\begin{array}{c}0.153^{* * *} \\
(0.040)\end{array}$ & $\begin{array}{l}0.016^{*} \\
(0.009)\end{array}$ \\
\hline Observations & 12,321 & 12,180 & 12,332 & 14,110 & 14,110 \\
\hline R-squared & 0.062 & 0.355 & 0.125 & 0.360 & 0.128 \\
\hline Number of firms & 3,327 & 3,073 & 3,265 & 3,467 & 3,467 \\
\hline Firm FE & Yes & Yes & Yes & Yes & Yes \\
\hline Event year FE & Yes & Yes & Yes & Yes & Yes \\
\hline SIC x calendar year FE & Yes & Yes & Yes & Yes & Yes \\
\hline IPO month x Post FE & Yes & Yes & Yes & Yes & Yes \\
\hline Regression & OLS & OLS & OLS & OLS & OLS \\
\hline
\end{tabular}


Table 5: First Stage IPO Results based on Returns

This table shows first-stage regressions according to the instrument (columns 1 and 2) and a placebo instrument (columns 3 and 4). Column 1 presents results where the instrument is the return over the 30 days before an IPO is completed or withdrawn. Column 2 shows similar results but using a dummy variable that takes a value of 1 if 30-day returns are positive or not. Columns 3 and 4 repeat the analyses of columns 1 and 2, but using the market returns in the 30 days after the IPO is completed or withdrawn. The sample is restricted to observations where ROA is available. We report the Kleibergen-Paap F-test for weak instruments that is robust to non-i.i.d. errors. Standard errors (in parentheses) are adjusted for heteroscedasticity and clustered at the firm level. Significant at: ${ }^{*} 10 \%,{ }^{*} 5 \%$ and $* * * 1 \%$.

\begin{tabular}{lcccc}
\hline & $(1)$ & $(2)$ & $(3)$ & $(4)$ \\
VARIABLES & IPO & IPO & IPO & IPO \\
\hline & & & & \\
Returns 30 days x Post & $0.434^{* * *}$ & & & \\
& $(0.121)$ & & & \\
Positive 30-day ret x Post & & $0.069^{* * *}$ & & \\
& & $(0.013)$ & & \\
Returns 30 days forward x Post & & & 0.130 & \\
& & & & $0.107)$ \\
Positive 30 days forward x Post & & & & $(0.018)$ \\
& & & & \\
Observations & 12,189 & 12,189 & 12,189 & 12,189 \\
R-squared & 0.894 & 0.894 & 0.893 & 0.893 \\
Number of firms & 3,195 & 3,195 & 3,195 & 3,195 \\
Firm FE & Yes & Yes & Yes & Yes \\
Event year FE & Yes & Yes & Yes & Yes \\
SIC x calendar year FE & Yes & Yes & Yes & Yes \\
IPO month x Post FE & Yes & Yes & Yes & Yes \\
Regression & First stage & First stage & Placebo & Placebo \\
& \multicolumn{3}{c}{ First stage } & First stage \\
K-P F-stat & 12.69 & 27.84 & 1.48 & 0.69 \\
\hline
\end{tabular}


Table 6: Instrumental Variable Results

This table shows the second stage regressions results. The instrument is a dummy variable for high returns pre IPO attempt times the Post dummy (Positive 30-day ret x Post), as shown in column 2 of Table 5. Standard errors (in parentheses) are adjusted for heteroscedasticity and clustered at the firm level. Significant at: ${ }^{*} 10 \%,{ }^{*} * 5 \%$ and $* * * 1 \%$.

\begin{tabular}{lccccc}
\hline & $(1)$ & $(2)$ & $(3)$ & $(4)$ & $(5)$ \\
VARIABLES & ROA & Asset growth & $\log ($ Sales $)$ & $\log ($ Subs. $)$ & $\log ($ Countries $)$ \\
\hline & & & & & \\
IPO & $0.233^{* *}$ & 0.935 & 0.740 & $1.042^{* * *}$ & $0.189^{* *}$ \\
& $(0.109)$ & $(0.676)$ & $(1.392)$ & $(0.335)$ & $(0.083)$ \\
Observations & & & & & \\
Number of firms & 12,189 & 12,155 & 12,208 & 14,110 & 14,110 \\
Firm FE & 3,195 & 3,048 & 3,141 & 3,467 & 3,467 \\
Event year FE & Yes & Yes & Yes & Yes & Yes \\
SIC x calendar year FE & Yes & Yes & Yes & Yes & Yes \\
IPO month x Post FE & Yes & Yes & Yes & Yes & Yes \\
Regression & Second stage & Second stage & Second stage & Second stage & Second stage \\
Instrument & Pre-IPO ret $>0$ & Pre-IPO ret $>0$ & Pre-IPO ret $>0$ & Pre-IPO ret $>0$ & Pre-IPO ret $>0$ \\
\hline
\end{tabular}




\section{Table 7: Reduced Form Results with the Return Instrument}

This table shows the results of the reduced-form regressions. Panel A shows the results where the dependent variables are run against the key instrument (Positive 30-day ret $\mathrm{x}$ Post), whereas panel B presents the results where the dependent variable are run against the placebo instrument (Positive 30-day ret fwd x Post). Standard errors (in parentheses) are adjusted for heteroscedasticity and clustered at the firm level. Significant at: ${ }^{*} 10 \%,{ }^{* *} 5 \%$ and $* * * 1 \%$.

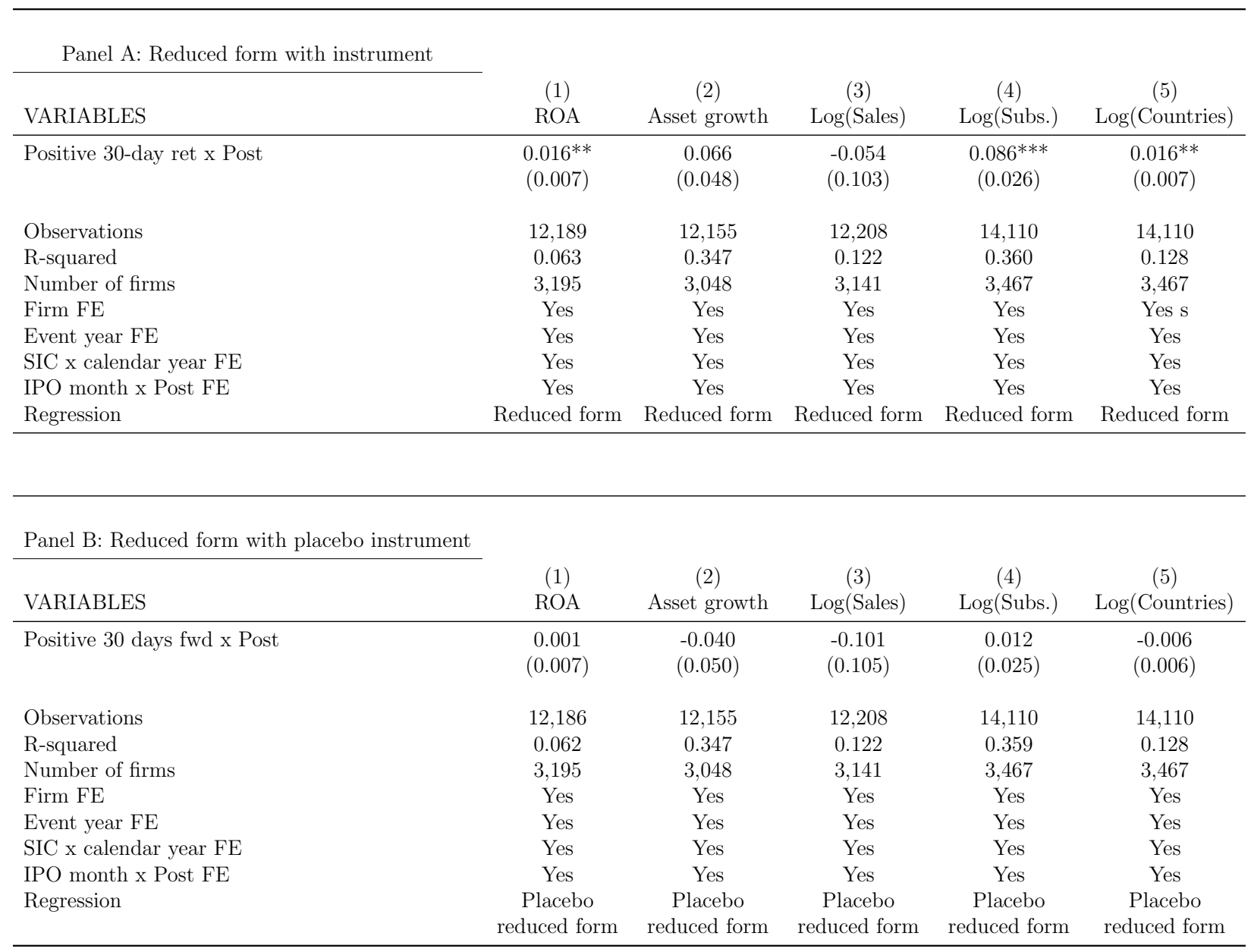


Table 8: Mechanisms: Financial Dependence

This table shows the second stage regressions results, additionally including the interaction of the IPO variable with an indicator for High Financial Dependence (see Table A.2), which takes a value of 1 if the firm operates in an industry with Financial Dependence above the sample mean, and 0 otherwise. To obtain the instrumented interaction coefficient, we extend the first-stage regression to include as an additional instrument Positive 30-day ret x Post $\mathrm{x}$ High Fin. Dep., as shown in columns 1 and 2 of Table A.5. Standard errors (in parentheses) are adjusted for heteroscedasticity and clustered at the firm level. Significant at: ${ }^{*} 10 \%$, $* * 5 \%$ and $* * * 1 \%$.

\begin{tabular}{|c|c|c|c|c|c|}
\hline VARIABLES & $\begin{array}{c}(1) \\
\mathrm{ROA}\end{array}$ & $\begin{array}{c}(2) \\
\text { Asset growth }\end{array}$ & $\begin{array}{c}(3) \\
\log (\text { Sales })\end{array}$ & $\begin{array}{c}(4) \\
\log (\text { Subs. })\end{array}$ & $\begin{array}{c}(5) \\
\log (\text { Countries })\end{array}$ \\
\hline IPO & $\begin{array}{c}0.221^{* *} \\
(0.108)\end{array}$ & $\begin{array}{c}0.880 \\
(0.675)\end{array}$ & $\begin{array}{c}0.746 \\
(1.394)\end{array}$ & $\begin{array}{c}1.087^{* * *} \\
(0.338)\end{array}$ & $\begin{array}{l}0.195^{*} \\
(0.083)\end{array}$ \\
\hline IPO x High Fin. Dep. & $\begin{array}{c}0.056^{* * *} \\
(0.020)\end{array}$ & $\begin{array}{l}0.253^{* *} \\
(0.121)\end{array}$ & $\begin{array}{l}-0.022 \\
(0.234)\end{array}$ & $\begin{array}{c}-0.246^{* * *} \\
(0.053)\end{array}$ & $\begin{array}{l}-0.034^{* *} \\
(0.014))\end{array}$ \\
\hline Observations & 12,189 & 12,155 & 12,208 & 14,110 & 14,110 \\
\hline Number of firms & 3,195 & 3,048 & 3,141 & 3,467 & 3,467 \\
\hline Firm FE & Yes & Yes & Yes & Yes & Yes \\
\hline Event year FE & Yes & Yes & Yes & Yes & Yes \\
\hline SIC $x$ calendar year FE & Yes & Yes & Yes & Yes & Yes \\
\hline IPO month x Post FE & Yes & Yes & Yes & Yes & Yes \\
\hline Regression & Second stage & Second stage & Second stage & Second stage & Second stage \\
\hline Instrument \#1 & Pre-IPO ret $>0$ & Pre-IPO ret $>0$ & Pre-IPO ret $>0$ & Pre-IPO ret $>0$ & Pre-IPO ret $>0$ \\
\hline Instrument \#2 & $\begin{array}{c}\text { Pre-IPO ret }>0 \\
\text { x High Fin.Dep. }\end{array}$ & $\begin{array}{l}\text { Pre-IPO ret }>0 \\
\text { x High Fin.Dep. }\end{array}$ & $\begin{array}{l}\text { Pre-IPO ret }>0 \\
\text { x High Fin.Dep. }\end{array}$ & $\begin{array}{c}\text { Pre-IPO ret }>0 \\
\text { x High Fin.Dep. }\end{array}$ & $\begin{array}{l}\text { Pre-IPO ret }>0 \\
\text { x High Fin.Dep. }\end{array}$ \\
\hline
\end{tabular}




\section{Table 9: Mechanisms: Investor Protection}

This table shows the second stage regressions results, additionally including the interaction of the IPO variable with an indicator for High anti-self-dealing index (see Table A.2), which takes a value of 1 if the firm operates in a country with investor protection above the sample mean, and 0 otherwise. To obtain the instrumented interaction coefficient, we extend the first-stage regression to include as an additional instrument Positive 30-day ret x Post x High anti-self-dealing, as shown in columns 3 and 4 of Table A.5. Standard errors (in parentheses) are adjusted for heteroscedasticity and clustered at the firm level. Significant at: ${ }^{*} 10 \%,{ }^{*} 5 \%$ and $* * * 1 \%$.

\begin{tabular}{lccccc}
\hline \multirow{2}{*}{ VARIABLES } & $(1)$ & $(2)$ & $(3)$ & $(4)$ & $(5)$ \\
ROA & Asset growth & $\log ($ Sales $)$ & $\log ($ Subs. $)$ & $\log ($ Countries $)$ \\
\hline IPO & $0.222^{* *}$ & 0.769 & 0.649 & $1.000^{* * *}$ & $0.215^{* * *}$ \\
& $(0.108)$ & $(0.658)$ & $(1.377)$ & $(0.331)$ & $(0.083)$ \\
IPO x High anti-self-dealing & $0.025^{* *}$ & $0.268^{* * *}$ & 0.169 & $0.079^{*}$ & $-0.050^{* * *}$ \\
& $(0.011)$ & $(0.073)$ & $(0.149)$ & $(0.041)$ & $(0.010)$ \\
Observations & & & & & \\
Number of firms & 12,189 & 12,155 & 12,208 & 14,110 & 14,110 \\
Firm FE & 3,195 & 3,048 & 3,141 & 3,467 & 3,467 \\
Event year FE & Yes & Yes & Yes & Yes & Yes \\
SIC x calendar year FE & Yes & Yes & Yes & Yes & Yes \\
IPO month x Post FE & Yes & Yes & Yes & Yes & Yes \\
Regression & Yes & Yes & Yes & Yes & Yes \\
Instrument \#1 & Second stage & Second stage & Second stage & Second stage & Second stage \\
Instrument \#2 & Pre-IPO ret>0 & Pre-IPO ret $>0$ & Pre-IPO ret $>0$ & Pre-IPO ret $>0$ & Pre-IPO ret $>0$ \\
& Pre-IPO ret $>0$ & Pre-IPO ret $>0$ & Pre-IPO ret $>0$ & Pre-IPO ret $>0$ & Pre-IPO ret $>0$ \\
& x High anti-sd & x High anti-sd & x High anti-sd & x High anti-sd & x High anti-sd \\
& & & & & \\
\hline
\end{tabular}


Table 10: Mechanisms: Country-level Index of IPO Disclosure

This table shows the second stage regressions results, additionally including the interaction of the IPO variable with an indicator for High disclosure index (see Table A.2), which takes a value of 1 if the firm operates in a country with IPO disclosure requirements above the sample mean, and 0 otherwise. To obtain the instrumented interaction coefficient, we extend the first-stage regression to include as an additional instrument Positive 30-day ret x Post $\mathrm{x}$ High disclosure., as shown in columns 5 and 6 of Table A.5. Standard errors (in parentheses) are adjusted for heteroscedasticity and clustered at the firm level. Significant at: ${ }^{*} 10 \%$, $* * 5 \%$ and $* * * 1 \%$.

\begin{tabular}{lccccc}
\hline \multirow{2}{*}{ VARIABLES } & $(1)$ & $\begin{array}{c}(2) \\
\text { Asset growth }\end{array}$ & $\begin{array}{c}(3) \\
\log (\text { Sales })\end{array}$ & $\begin{array}{c}(4) \\
\log (\text { Subs. })\end{array}$ & $\begin{array}{c}(5) \\
\log (\text { Countries })\end{array}$ \\
\hline IPO & ROA & 0.798 & 0.831 & $0.973^{* * *}$ & $0.253^{* * *}$ \\
& $(0.112)$ & $(0.700)$ & $(1.494)$ & $(0.346)$ & $(0.091)$ \\
IPO x High disclosure & $0.024^{* *}$ & 0.111 & -0.069 & 0.059 & $-0.055^{* * *}$ \\
& $(0.011)$ & $(0.071)$ & $(0.156)$ & $(0.040)$ & $(0.011)$ \\
Observations & & & & & \\
Number of firms & 12,189 & 12,155 & 12,208 & 14,110 & 14,110 \\
Firm FE & 3,195 & 3,048 & 3,141 & 3,467 & 3,467 \\
Event year FE & Yes & Yes & Yes & Yes & Yes \\
SIC x calendar year FE & Yes & Yes & Yes & Yes & Yes \\
IPO month x Post FE & Yes & Yes & Yes & Yes & Yes \\
Regression & Second stage & Second stage & Second stage & Second stage & Second stage \\
Instrument \#1 & Pre-IPO ret $>0$ & Pre-IPO ret $>0$ & Pre-IPO ret $>0$ & Pre-IPO ret $>0$ & Pre-IPO ret $>0$ \\
Instrument \# & Pre-IPO ret $>0$ & Pre-IPO ret $>0$ & Pre-IPO ret $>0$ & Pre-IPO ret $>0$ & Pre-IPO ret $>0$ \\
& x High discl. & x High discl. & x High discl. & x High discl. & x High discl. \\
\hline
\end{tabular}


This table shows the second stage regressions results using the logarithm of one plus patent applications as the dependent variable. Patents are measured as the moving average of applications granted in years $t, t+1$, and $t+2$. (see Table A.2). Columns 2-4 additionally include the interaction of the instrumented IPO dummy with cross-sectional dummies based on industry or country-level characteristics. Standard errors (in parentheses) are adjusted for heteroscedasticity and clustered at the firm level. Significant at: ${ }^{*} 10 \%, * * 5 \%$ and ${ }^{* * *} 1 \%$.

\begin{tabular}{|c|c|c|c|c|}
\hline VARIABLES & $\begin{array}{c}(1) \\
\log (\text { patents })\end{array}$ & $\begin{array}{c}(2) \\
\log (\text { patents })\end{array}$ & $\begin{array}{c}(3) \\
\log (\text { patents })\end{array}$ & $\begin{array}{c}(4) \\
\log (\text { patents })\end{array}$ \\
\hline $\mathrm{IPO}$ & $\begin{array}{l}-0.054 \\
(0.115)\end{array}$ & $\begin{array}{l}-0.059 \\
(0.108)\end{array}$ & $\begin{array}{l}-0.035 \\
(0.110)\end{array}$ & $\begin{array}{c}0.003 \\
(0.121)\end{array}$ \\
\hline IPO x High Ind. Fin. Dep & & $\begin{array}{c}0.001 \\
(0.021)\end{array}$ & & \\
\hline IPO x High Anti self-dealing & & & $\begin{array}{c}-0.041^{* * *} \\
(0.012)\end{array}$ & \\
\hline IPO x High Disclosure & & & & $\begin{array}{c}-0.051^{* * *} \\
(0.015)\end{array}$ \\
\hline Observations & 14,110 & 14,110 & 14,110 & 14,110 \\
\hline Number of firms & 3,467 & 3,467 & 3,467 & 3,467 \\
\hline Firm FE & Yes & Yes & Yes & Yes \\
\hline Event year FE & Yes & Yes & Yes & Yes \\
\hline SIC x calendar year FE & Yes & Yes & Yes & Yes \\
\hline IPO month x Post FE & Yes & Yes & Yes & Yes \\
\hline Regression & Second stage & Second stage & Second stage & Second stage \\
\hline Instrument \#1 & Pre-IPO ret $>0$ & Pre-IPO ret $>0$ & Pre-IPO ret $>0$ & Pre-IPO ret $>0$ \\
\hline Instrument \#2 & & $\begin{array}{l}\text { Pre-IPO ret }>0 \\
\text { x High Fin.Dep. }\end{array}$ & $\begin{array}{l}\text { Pre-IPO ret }>0 \\
x \text { High anti-sd }\end{array}$ & $\begin{array}{c}\text { Pre-IPO ret }>0 \\
\text { x High discl. }\end{array}$ \\
\hline
\end{tabular}


Table 12: Other Capital Raising and Corporate Governance Outcomes

This table shows second stage results when dependent variables are the following: a dummy for years where shareholders' net funds growth is higher than $100 \%$ excluding the year of the IPO (column 1), a dummy for years where debt growth is higher than $100 \%$ (column 2), a dummy for years with a change in CEO or CFO (columns 3 and 4). Standard errors (in parentheses) are adjusted for heteroscedasticity and clustered at the firm level. Significant at: ${ }^{*} 10 \%,{ }^{* *} 5 \%$ and $* * * 1 \%$.

\begin{tabular}{|c|c|c|c|c|}
\hline VARIABLES & $\begin{array}{l}\text { (1) } \\
\text { Shareholder's net funds } \\
\text { growth }>100 \% \text { excl. IPO }\end{array}$ & $\begin{array}{c}(2) \\
\text { Debt growth }>100 \%\end{array}$ & $\begin{array}{c}(3) \\
\text { CEO change }\end{array}$ & $\begin{array}{c}(4) \\
\text { CFO change }\end{array}$ \\
\hline IPO & $\begin{array}{c}0.008 \\
(0.219)\end{array}$ & $\begin{array}{c}-0.575^{* *} \\
(0.273)\end{array}$ & $\begin{array}{l}0.149^{*} \\
(0.090)\end{array}$ & $\begin{array}{c}0.056^{* *} \\
(0.028)\end{array}$ \\
\hline Observations & 8,941 & 9,182 & 14,110 & 14,110 \\
\hline Number of firms & 2,751 & 2,813 & 3,467 & 3,467 \\
\hline Firm FE & Yes & Yes & Yes & Yes \\
\hline Event year FE & Yes & Yes & Yes & Yes \\
\hline SIC $x$ calendar year FE & Yes & Yes & Yes & Yes \\
\hline IPO month $x$ Post FE & Yes & Yes & Yes & Yes \\
\hline Instrument & Pre-IPO ret $>0$ & Pre-IPO ret $>0$ & Pre-IPO ret $>0$ & Pre-IPO ret $>0$ \\
\hline
\end{tabular}


Appendix 


\section{Sample Selection}

\section{From raw data to final sample}

- IPO attempts with valid IPO-attempt dates and data before and after the attempt: 3,534 .

- Define a 5-year event window around the event: from -2 to +2 .

- Exclude firms with overlapping withdrawn IPO and a completed IPO events: 52 events.

- Exclude the first withdrawn event that is followed by another withdrawn event within 5 years: 15 events.

- 12 were followed by another withdrawn event included in the sample.

- 2 were followed by a non-overlapping withdrawn and completed IPO event included the sample.

- 1 was followed by overlapping withdrawn and completed IPO events not included in the sample.

- Final sample: 3,467 IPO attempts (=3,534-52-15)

- 430 withdrawn and 3,037 completed.

- Final sample includes:

* 12 withdrawn attempts that represent the follow-up withdrawn attempt within a 5-year interval.

* 19 firms (38 events) that have a withdrawn attempt followed by a completed IPO more than 5 years apart (non-overlapping events). 


\section{Firms that withdraw}

- Combining the included and excluded events from the sample there are 456 firms that withdraw their IPOs.

- 408 firms that withdraw their IPO do not file again.

- 48 attempt to go public again.

- 36 eventually go public later on.

- Mean (median) time between a withdrawn IPO attempt and the next attempt is 2.4 (0.5) years.

- Mean (median) time between a withdrawn IPO attempt and the next withdrawn attempt is 2.2 years $(0.16$ year $=2$ months $)$.

- Mean (median) time between a withdrawn IPO attempt and a completed IPO is 2.5 years (1.2 years). 
Figure A.1: Statistical Inference when Excluding Clusters

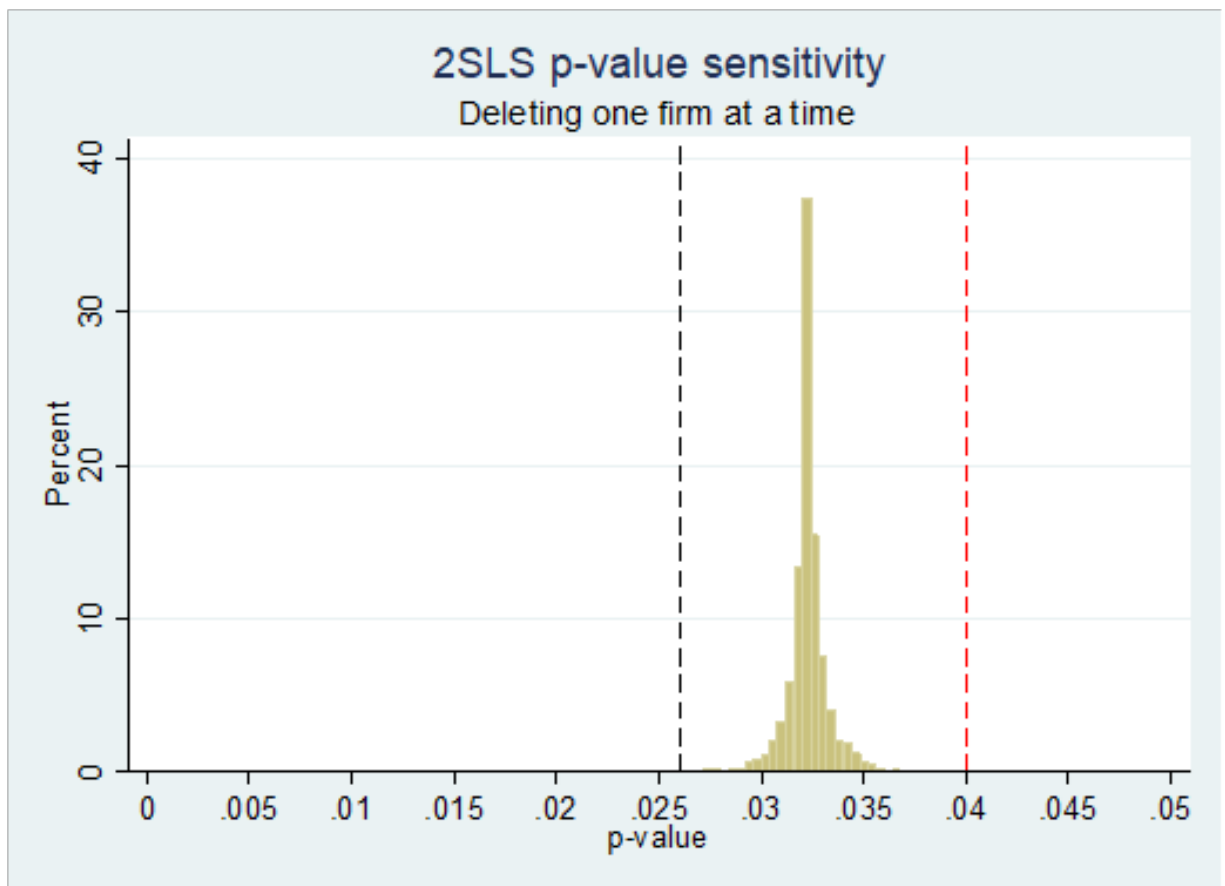

(a)

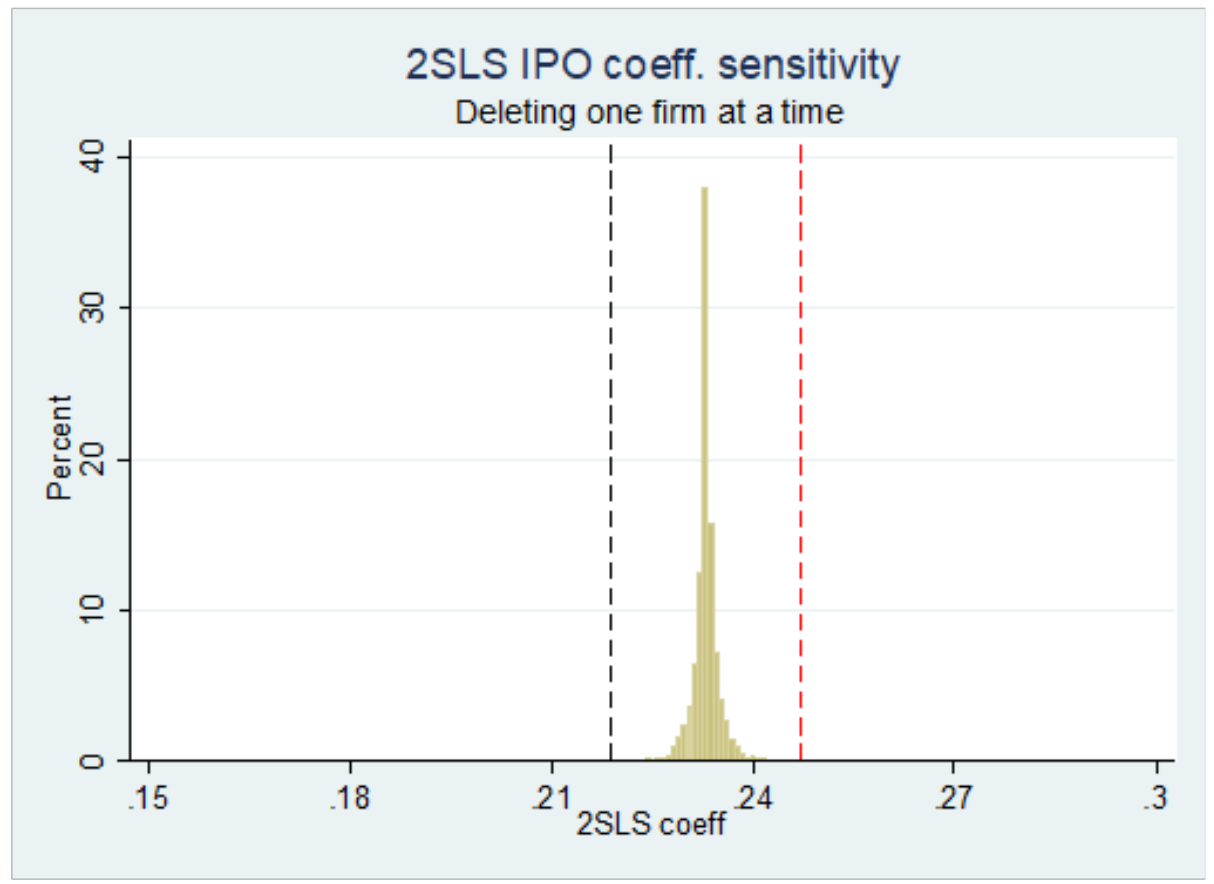

(b)

Notes: The figure shows the distribution of $p$-values (panel a) and $\beta$ coefficients (panel b) from the second stage ROA regression of the multiple samples that result from excluding one firm (cluster) at a time. Dashed vertical lines show the maximum and minimum values obtained. 
Table A.1: Robustness to Sample Selection and Regression Specification

This table shows the first stage (Panel A) and second stage (Panel B) results for ROA across different samples and specifications: baseline sample (column 1), adding excluded IPOs (column 2), dropping non-overlapping attempts (column 3), dropping firms with previous withdrawn attempts (column 4), dropping cross-listings (column 5), and adding industrytimes-year fixed effects when industries are defined at the 2-digit SIC level (column 6). Standard errors (in parentheses) are adjusted for heteroscedasticity and clustered at the firm level. Significant at: $* 10 \%, * * 5 \%$ and $* * * 1 \%$.

\begin{tabular}{lcccccc}
\hline Sample/ Specification & $\begin{array}{c}(1) \\
\text { Baseline }\end{array}$ & $\begin{array}{c}(2) \\
\text { plus excl. } \\
\text { IPOs }\end{array}$ & $\begin{array}{c}(3) \\
\text { drop non- } \\
\text { overlap }\end{array}$ & $\begin{array}{c}(4) \\
\text { drop prev. } \\
\text { withdrawn }\end{array}$ & $\begin{array}{c}(5) \\
\text { drop } \\
\text { cross-list }\end{array}$ & $\begin{array}{c}\text { 2-dig-SIC x } \\
\text { Year FE }\end{array}$ \\
\hline \multicolumn{1}{c}{ Panel A: 1st Stage } & IPO & IPO & IPO & IPO & IPO & IPO \\
\hline Positive 30-day ret x Post & $0.069^{* * *}$ & $0.078^{* * *}$ & $0.070^{* * *}$ & $0.066^{* * *}$ & $0.068^{* * *}$ & $0.068^{* * *}$ \\
& $(0.013)$ & $(0.013)$ & $(0.013)$ & $(0.013)$ & $(0.013)$ & $(0.013)$ \\
& & & & & & \\
\hline \multicolumn{1}{c}{ Panel B: 2nd Stage } & ROA & ROA & ROA & ROA & ROA & ROA \\
\hline IPO & $0.233^{* *}$ & $0.210^{* *}$ & $0.237^{* *}$ & $0.250^{* *}$ & $0.258^{* *}$ & $0.253^{* *}$ \\
& $(0.109)$ & $(0.093)$ & $(0.108)$ & $(0.116)$ & $(0.114)$ & $(0.117)$ \\
Observations & & & & & & \\
Number of firms & 12,189 & 12,450 & 12,076 & 12,143 & 11,891 & 12,189 \\
Firm FE & 3,195 & 3,259 & 3,165 & 3,183 & 3,123 & 3,195 \\
Event year FE & Yes & Yes & Yes & Yes & Yes & Yes \\
SIC x calendar year FE & Yes & Yes & Yes & Yes & Yes & Yes \\
IPO month x Post FE & Yes & Yes & Yes & Yes & Yes & Yes \\
1st Stage K-P F-stat & Yes & Yes & Yes & Yes & Yes & Yes \\
\hline & 27.84 & 34.44 & 28.6 & 26.04 & 26.16 & 35.55 \\
\hline
\end{tabular}


Table A.2: Additional Summary Statistics

This table summary statistics for additional variables. $\log$ (patents) is the logarithm of 1 plus the number of (eventually granted) applications in a year for years before the IPO attempt. For years after the IPO we use 3-years rolling averages going forward to get at long-run effects: patents $(\mathrm{t})=[$ patents $(\mathrm{t})+$ patents $(\mathrm{t}+1)+$ patents $(\mathrm{t}+2)] / 3$. Acquisitions is the number of acquisitions undertaken by a firm in a year for years prior to the IPO attempt. For years after the IPO we use 3-years rolling averages going forward to get at long-run effects: acquisitions $(\mathrm{t})=[\operatorname{acquisitions}(\mathrm{t})+\operatorname{acquisitions}(\mathrm{t}+1)+\operatorname{acquisitions}(\mathrm{t}+2)] / 3$. Target is an indicator variable that takes a value of 1 if the firm is the target of an acquisition during the first 5 years after the IPO attempt. Financial Dependence is measure of financial dependence index computed using Rajan and Zingales (1998) methodology at the 3-digit SIC code level. Higher financial dependence means higher needs of external financing. Anti-self-dealing is a measure of legal protection of minority shareholders against expropriation by corporate insiders at the country level, following Djankov, La Porta, Lopez-de-Silanes, and Shleifer (2008). Disclosure Measure of disclosure of initial public offerings at the country level, following La Porta, Lopez-de-Silanes, and Shleifer (2006).

\begin{tabular}{lrrrrrrrl}
\hline & Mean & P10 & P25 & P50 & P75 & P90 & SD & Total \\
\hline Log(patents) & 0.06 & 0 & 0 & 0 & 0 & 0 & 0.41 & 14,410 \\
Log(acquisition) & 0.18 & 0 & 0 & 0 & 0 & 0.69 & 0.39 & 14,410 \\
Target & 0.03 & 0 & 0 & 0 & 0 & 0 & 0.17 & 14,410 \\
Ind. Fin. Dep. & 0.90 & 0.53 & 0.87 & 1 & 1 & 1.17 & 1.02 & 14,410 \\
Anti-self-dealing & 0.56 & 0.28 & 0.33 & 0.42 & 0.95 & 0.95 & 0.29 & 14,410 \\
Disclosure & 0.66 & 0.42 & 0.50 & 0.67 & 0.83 & 0.83 & 0.16 & 14,410 \\
\hline
\end{tabular}


Table A.3: First and Second Stage Results with Alternative Return Instruments

This table shows the first stage (columns 1-8) and second stage (columns 9-10) results for ROA when using market returns at different horizons (30, 60 or 90 days before the IPO attempt). Standard errors (in parentheses) are adjusted for heteroscedasticity and clustered at the firm level. Significant at: ${ }^{*} 10 \%, * * 5 \%$ and $* * * 1 \%$.

\begin{tabular}{|c|c|c|c|c|c|c|c|c|c|c|}
\hline & $\begin{array}{c}(1) \\
\text { IPO }\end{array}$ & $\begin{array}{l}(2) \\
\text { IPO }\end{array}$ & $\begin{array}{l}(3) \\
\text { IPO }\end{array}$ & $\begin{array}{l}(4) \\
\text { IPO }\end{array}$ & $\begin{array}{l}(5) \\
\text { IPO }\end{array}$ & $\begin{array}{c}(6) \\
\text { IPO }\end{array}$ & $\begin{array}{c}(7) \\
\text { IPO }\end{array}$ & $\begin{array}{l}(8) \\
\text { IPO }\end{array}$ & $\begin{array}{c}(9) \\
\text { ROA }\end{array}$ & $\begin{array}{l}(10) \\
\text { ROA }\end{array}$ \\
\hline IPO & & & & & & & & & $\begin{array}{c}0.183^{* *} \\
(0.091)\end{array}$ & $\begin{array}{c}0.162^{* *} \\
(0.082)\end{array}$ \\
\hline Returns 30 days x Post & & & & & $\begin{array}{c}0.481^{* * *} \\
(0.121)\end{array}$ & & $\begin{array}{c}0.460^{* * * *} \\
(0.120)\end{array}$ & & & \\
\hline Pos. 30-day ret x Post & & & & & & $\begin{array}{c}0.071^{* * *} \\
(0.013)\end{array}$ & & $\begin{array}{c}0.070^{* * *} \\
(0.013)\end{array}$ & & \\
\hline Returns (60-30) days x Post & $\begin{array}{c}0.340^{* * *} \\
(0.109)\end{array}$ & & & & $\begin{array}{c}0.390^{* * *} \\
(0.111)\end{array}$ & & $\begin{array}{c}0.392^{* * *} \\
(0.112)\end{array}$ & & & \\
\hline Pos. (60-30)-day ret x Post & & $\begin{array}{c}0.042^{* * *} \\
(0.013)\end{array}$ & & & & $\begin{array}{c}0.045^{* * *} \\
(0.013)\end{array}$ & & $\begin{array}{c}0.049^{* * *} \\
(0.013)\end{array}$ & & \\
\hline Returns (90-60) days x Post & & & $\begin{array}{l}0.194^{*} \\
(0.101)\end{array}$ & & & & $\begin{array}{l}0.175^{*} \\
(0.102)\end{array}$ & & & \\
\hline Pos. (90-60)-day ret x Post & & & & $\begin{array}{c}0.038^{* * *} \\
(0.013)\end{array}$ & & & & $\begin{array}{c}0.039 * * * \\
(0.013)\end{array}$ & & \\
\hline Observations & 12,189 & 12,189 & 12,175 & 12,175 & 12,189 & 12,189 & 12,175 & 12,175 & 12,189 & 12,175 \\
\hline R-squared & 0.893 & 0.893 & 0.893 & 0.894 & 0.894 & 0.895 & 0.895 & 0.895 & & \\
\hline Number of firms & 3,195 & 3,195 & 3,192 & 3,192 & 3,195 & 3,195 & 3,192 & 3,192 & 3,195 & 3,192 \\
\hline Firm FE & Yes & Yes & Yes & Yes & Yes & Yes & Yes & Yes & Yes & Yes \\
\hline Event year FE & Yes & Yes & Yes & Yes & Yes & Yes & Yes & Yes & Yes & Yes \\
\hline SIC x calendar year FE & Yes & Yes & Yes & Yes & Yes & Yes & Yes & Yes & Yes & Yes \\
\hline IPO month x Post FE & Yes & Yes & Yes & Yes & Yes & Yes & Yes & Yes & Yes & Yes \\
\hline Stage & First & First & First & First & First & First & First & First & Second & Second \\
\hline 1st Stage K-P F-stat & 9.72 & 9.93 & 3.68 & 8.04 & 13.55 & 19.53 & 9.08 & 15.02 & & \\
\hline Instruments & & & & & & & & & Col. (6) & Col. (8) \\
\hline
\end{tabular}


Table A.4: Double Sort by Market Returns and IPO Status

The table shows averages of the main variables for double sorts of previous returns and listed status. High (High ret.) and low (Low ret.) market returns are measured in the 30 days prior to the IPO attempt. Listed status corresponds to completed IPOs (IPO) and withdrawn (Withdr.) IPOs. In Panel A, high (low) returns are those above (below) the sample mean, while in Panel B, high (low) returns are those above (below) the 25th percentile in the sample.

\begin{tabular}{|c|c|c|c|c|}
\hline \multirow[b]{3}{*}{ Variable (pre IPO attempt) } & \multicolumn{4}{|c|}{ Panel A: All Compliers } \\
\hline & \multirow{2}{*}{$\begin{array}{c}\text { Always-Takers } \\
\text { Low Ret./ IPO }\end{array}$} & \multicolumn{2}{|c|}{ Compliers } & \multirow{2}{*}{$\begin{array}{c}\text { Never-Takers } \\
\text { High Ret./ Withdr. }\end{array}$} \\
\hline & & High Ret./ IPO & Low Ret./ Withdr. & \\
\hline ROA & -0.008 & -0.021 & 0.008 & 0.021 \\
\hline Assets (MM) & 137.28 & 134.25 & 243.82 & 266.23 \\
\hline Asset growth & -0.034 & -0.024 & -0.046 & -0.037 \\
\hline Leverage & 0.55 & 0.54 & 0.55 & 0.60 \\
\hline Sales (MM) & 256.28 & 254.13 & 516.69 & 582.94 \\
\hline Subsidiaries & 1.33 & 1.43 & 1.39 & 2.14 \\
\hline Countries & 1.08 & 1.10 & 1.10 & 1.25 \\
\hline \multirow[t]{3}{*}{ \# of firms } & 1,446 & 1,591 & 278 & 152 \\
\hline & \multicolumn{4}{|c|}{ Panel B: Extreme Compliers } \\
\hline & Always-Takers & \multicolumn{2}{|c|}{ Compliers } & Never-Takers \\
\hline Variable (pre IPO attempt) & Low Ret./ IPO & High Ret./ IPO & Low Ret./ Withdr. & High Ret./ Withdr. \\
\hline $\mathrm{ROA}$ & -0.015 & -0.015 & 0.021 & 0.007 \\
\hline Assets (MM) & 138.54 & 127.64 & 205.29 & 282.31 \\
\hline Asset growth & -0.034 & -0.015 & -0.051 & -0.038 \\
\hline Leverage & 0.54 & 0.55 & 0.56 & 0.58 \\
\hline Sales (MM) & 258.79 & 245.14 & 392.35 & 640.95 \\
\hline Subsidiaries & 1.32 & 1.55 & 1.47 & 1.79 \\
\hline Countries & 1.08 & 1.11 & 1.11 & 1.19 \\
\hline \# of firms & 2,237 & 800 & 176 & 254 \\
\hline
\end{tabular}




\section{Table A.5: First Stage for Interactions}

This table shows the first-stage regressions that include interaction terms with High. Fin. Dep, High anti-self-dealing, and High disclosure. The first stage regressions presented in columns 1 and 2 are used to generate the second stage results presented in Table 8 . The first stage regressions presented in columns 3 and 4 are used to generate the second stage results presented in Table 9. The first stage regressions presented in columns 3 and 4 are used to generate the second stage results presented in Table 10. The sample is restricted to observations where ROA is available. Standard errors (in parentheses) are adjusted for heteroscedasticity and clustered at the firm level. Significant at: ${ }^{*} 10 \%,{ }^{*} * 5 \%$ and $* * * 1 \%$.

\begin{tabular}{|c|c|c|c|c|c|c|}
\hline VARIABLES & $\begin{array}{l}(1) \\
\text { IPO }\end{array}$ & $\begin{array}{c}(2) \\
\text { IPO x High Fin. Dep. }\end{array}$ & $\begin{array}{l}(3) \\
\text { IPO }\end{array}$ & $\begin{array}{c}(4) \\
\text { IPO x High Anti sd }\end{array}$ & $\begin{array}{l}(5) \\
\text { IPO }\end{array}$ & $\begin{array}{c}(6) \\
\text { IPO x High Discl. }\end{array}$ \\
\hline Positive 30-day ret x Post & $\begin{array}{c}0.068^{* * *} \\
(0.014)\end{array}$ & $\begin{array}{c}-0.075^{* * *} \\
(0.007)\end{array}$ & $\begin{array}{c}0.081^{* * *} \\
(0.014)\end{array}$ & $\begin{array}{c}-0.391 * * * \\
(0.015)\end{array}$ & $\begin{array}{c}0.055^{* * *} \\
(0.015)\end{array}$ & $\begin{array}{c}-0.363^{* * *} \\
(0.015)\end{array}$ \\
\hline Positive 30-day ret x Post $x$ High Fin. Dep & $\begin{array}{l}-0.014 \\
(0.020)\end{array}$ & $\begin{array}{c}0.881^{* * * *} \\
(0.019)\end{array}$ & & & & \\
\hline Positive 30-day ret x Post x High Anti self-dealing & & & $\begin{array}{l}-0.025^{*} \\
(0.014)\end{array}$ & $\begin{array}{c}0.874^{* * *} \\
(0.012)\end{array}$ & & \\
\hline Positive 30-day ret x Post x High Disclosure & & & & & $\begin{array}{c}0.028^{* *} \\
(0.014)\end{array}$ & $\begin{array}{c}0.902^{* * *} \\
(0.010)\end{array}$ \\
\hline Observations & 12,189 & 12,189 & 12,189 & 12,189 & 12,189 & 12,189 \\
\hline R-squared & 0.894 & 0.698 & 0.894 & 0.738 & 0.894 & 0.760 \\
\hline Number of firms & 3,195 & 3,195 & 3,195 & 3,195 & 3,195 & 3,195 \\
\hline Firm FE & Yes & Yes & Yes & Yes & Yes & Yes \\
\hline Event year FE & Yes & Yes & Yes & Yes & Yes & Yes \\
\hline SIC $x$ calendar year FE & Yes & Yes & Yes & Yes & Yes & Yes \\
\hline IPO month $\mathrm{x}$ Post FE & Yes & Yes & Yes & Yes & Yes & Yes \\
\hline Regression & First stage & First stage & First stage & First stage & First stage & First stage \\
\hline
\end{tabular}


Table A.6: Interactions with Other Proxies for Financial Constraints

This table shows the second stage results including the interaction of the IPO variable with three proxies for financial constraints: a dummy for small firms, a dummy for high leverage firms, and firm age. The regression specification is the same as in Table 8. In particular, the additional instrument in each panel is the interaction of Positive 30-day ret $\mathrm{x}$ Post $\mathrm{x}$ Proxy Financial Constraint. Standard errors (in parentheses) are adjusted for heteroscedasticity and clustered at the firm level. Significant at: ${ }^{*} 10 \%,{ }^{*} 5 \%$ and ${ }^{* * *} 1 \%$.

\begin{tabular}{|c|c|c|c|c|c|}
\hline & $\begin{array}{c}(1) \\
\mathrm{ROA}\end{array}$ & $\begin{array}{c}(2) \\
\text { Asset growth }\end{array}$ & $\begin{array}{c}(3) \\
\log (\text { Sales })\end{array}$ & $\begin{array}{c}(4) \\
\log (\text { Countries })\end{array}$ & $\begin{array}{c}(5) \\
\log (\text { Subs. })\end{array}$ \\
\hline \multicolumn{6}{|l|}{ Panel A: Small firms } \\
\hline $\mathrm{IPO}$ & $\begin{array}{c}0.238^{* *} \\
(0.109)\end{array}$ & $\begin{array}{c}0.557 \\
(0.653)\end{array}$ & $\begin{array}{c}0.528 \\
(1.401)\end{array}$ & $\begin{array}{c}1.198^{* * *} * \\
(0.336)\end{array}$ & $\begin{array}{c}0.220^{* * *} \\
(0.084)\end{array}$ \\
\hline IPO x Small & $\begin{array}{c}-0.027^{* *} \\
(0.012)\end{array}$ & $\begin{array}{c}0.944^{* * *} \\
(0.064)\end{array}$ & $\begin{array}{c}0.819^{* * *} \\
(0.152)\end{array}$ & $\begin{array}{c}-0.441^{* * *} \\
(0.047)\end{array}$ & $\begin{array}{c}-0.089^{* * *} \\
(0.012)\end{array}$ \\
\hline Observations & 12,189 & 12,155 & 12,208 & 14,110 & 14,110 \\
\hline Number of firms & 3,195 & 3,048 & 3,141 & 3,467 & 3,467 \\
\hline \multicolumn{6}{|l|}{ Panel B: High Leverage } \\
\hline IPO & $\begin{array}{c}0.236^{* *} \\
(0.108)\end{array}$ & $\begin{array}{l}1.120^{*} \\
(0.657)\end{array}$ & $\begin{array}{c}1.867 \\
(1.614)\end{array}$ & $\begin{array}{c}1.006^{* * *} \\
(0.373)\end{array}$ & $\begin{array}{c}0.231^{* *} \\
(0.096)\end{array}$ \\
\hline IPO x High Leverage & $\begin{array}{c}0.021^{* *} \\
(0.011)\end{array}$ & $\begin{array}{c}-0.475^{* * *} \\
(0.065)\end{array}$ & $\begin{array}{c}-0.776^{* * *} \\
(0.149)\end{array}$ & $\begin{array}{c}0.173^{* * *} \\
(0.044)\end{array}$ & $\begin{array}{c}0.017 \\
(0.011)\end{array}$ \\
\hline Observations & 11,297 & 11,201 & 10,984 & 12,593 & 12,593 \\
\hline Number of firms & 2,924 & 2,804 & 2,810 & 3,084 & 3,084 \\
\hline \multicolumn{6}{|l|}{ Panel C: Firm Age } \\
\hline IPO & $\begin{array}{c}0.233^{*} \\
(0.123)\end{array}$ & $\begin{array}{c}0.854 \\
(0.742)\end{array}$ & $\begin{array}{c}1.393 \\
(1.523)\end{array}$ & $\begin{array}{c}1.005^{* * *} \\
(0.356)\end{array}$ & $\begin{array}{c}0.183^{* *} \\
(0.088)\end{array}$ \\
\hline IPO x Age & $\begin{array}{c}0.000 \\
(0.000)\end{array}$ & $\begin{array}{c}-0.011^{* * *} \\
(0.002)\end{array}$ & $\begin{array}{c}-0.017^{* * *} \\
(0.005)\end{array}$ & $\begin{array}{c}0.006^{* * *} \\
(0.002)\end{array}$ & $\begin{array}{c}0.002^{* * *} \\
(0.001)\end{array}$ \\
\hline Observations & 11,014 & 11,095 & 10,939 & 12,767 & 12,767 \\
\hline Number of firms & 2,999 & 2,886 & 2,942 & 3,266 & 3,266 \\
\hline
\end{tabular}


Table A.7: Mechanisms: Triple Interactions with Country-level Investor Protection

This table shows the second stage regressions results, including triple interactions for IPO, industry High Fin. Dep., and the country-level measure of investor protection. The first stage regressions are adjusted accordingly to instrument for these interactions. Standard errors (in parentheses) are adjusted for heteroscedasticity and clustered at the firm level. Significant at: ${ }^{*} 10 \%,{ }^{*} 5 \%$ and $* * * 1 \%$.

\begin{tabular}{|c|c|c|c|c|c|}
\hline VARIABLES & $\begin{array}{c}(1) \\
\mathrm{ROA}\end{array}$ & $\begin{array}{c}(2) \\
\text { Asset growth }\end{array}$ & $\begin{array}{c}(3) \\
\log (\text { Sales })\end{array}$ & $\begin{array}{c}(4) \\
\log (\text { Subs. }) \\
\end{array}$ & $\begin{array}{c}(5) \\
\log (\text { Countries })\end{array}$ \\
\hline IPO & $\begin{array}{l}0.208^{*} \\
(0.106)\end{array}$ & $\begin{array}{c}0.688 \\
(0.655)\end{array}$ & $\begin{array}{c}0.580 \\
(1.380)\end{array}$ & $\begin{array}{c}1.040^{* * *} \\
(0.332)\end{array}$ & $\begin{array}{c}0.220^{* * *} \\
(0.083)\end{array}$ \\
\hline IPO x High Fin. Dep. & $\begin{array}{c}0.036 \\
(0.023)\end{array}$ & $\begin{array}{c}0.062 \\
(0.103)\end{array}$ & $\begin{array}{l}-0.320 \\
(0.269)\end{array}$ & $\begin{array}{c}-0.306^{* * *} \\
(0.067)\end{array}$ & $\begin{array}{c}-0.060^{* * *} \\
(0.020)\end{array}$ \\
\hline IPO x High Anti-self-dealing & $\begin{array}{l}0.021^{*} \\
(0.011)\end{array}$ & $\begin{array}{c}0.224^{* * *} \\
(0.077)\end{array}$ & $\begin{array}{c}0.087 \\
(0.157)\end{array}$ & $\begin{array}{c}0.063 \\
(0.045)\end{array}$ & $\begin{array}{c}-0.056^{* * *} \\
(0.011)\end{array}$ \\
\hline IPO x High F.D. x High Anti s.d. & $\begin{array}{c}0.050 \\
(0.038)\end{array}$ & $\begin{array}{l}0.356^{*} \\
(0.201)\end{array}$ & $\begin{array}{c}0.709 \\
(0.449)\end{array}$ & $\begin{array}{c}0.121 \\
(0.088)\end{array}$ & $\begin{array}{c}0.049^{* *} \\
(0.022)\end{array}$ \\
\hline Observations & 12,189 & 12,155 & 12,208 & 14,110 & 14,110 \\
\hline Number of firms & 3,195 & 3,048 & 3,141 & 3,467 & 3,467 \\
\hline Firm FE & Yes & Yes & Yes & Yes & Yes \\
\hline Event year FE & Yes & Yes & Yes & Yes & Yes \\
\hline SIC x calendar year FE & Yes & Yes & Yes & Yes & Yes \\
\hline IPO month $x$ Post FE & Yes & Yes & Yes & Yes & Yes \\
\hline Regression & Second stage & Second stage & Second stage & Second stage & Second stage \\
\hline Instrument \#1 & Pre-IPO ret $>0$ & Pre-IPO ret $>0$ & Pre-IPO ret $>0$ & Pre-IPO ret $>0$ & Pre-IPO ret $>0$ \\
\hline Instrument \#2 & Pre-IPO ret $>0$ & Pre-IPO ret $>0$ & Pre-IPO ret $>0$ & Pre-IPO ret $>0$ & Pre-IPO ret $>0$ \\
\hline Instrument \#3 & $\begin{array}{l}\text { x High Fin.Dep. } \\
\text { Pre-IPO ret }>0 \\
\text { x High anti-sd }\end{array}$ & $\begin{array}{c}\text { x High Fin.Dep. } \\
\text { Pre-IPO ret }>0 \\
\text { x High anti-sd }\end{array}$ & $\begin{array}{l}\text { x High Fin.Dep. } \\
\text { Pre-IPO ret }>0 \\
\text { x High anti-sd }\end{array}$ & $\begin{array}{l}\text { x High Fin.Dep. } \\
\text { Pre-IPO ret }>0 \\
\text { x High anti-sd }\end{array}$ & $\begin{array}{l}\text { x High Fin.Dep. } \\
\text { Pre-IPO ret }>0 \\
\text { x High anti-sd }\end{array}$ \\
\hline
\end{tabular}


Table A.8: Mechanisms: Triple Interactions with Country-level Disclosure Requirements

This table shows the second stage regressions results, including triple interactions for IPO, industry High Fin. Dep., and country-level measure of disclosure requirements. The first stage regressions are adjusted accordingly to instrument for these interactions. Standard errors (in parentheses) are adjusted for heteroscedasticity and clustered at the firm level. Significant at: ${ }^{*} 10 \%,{ }^{*} 5 \%$ and $* * * 1 \%$.

\begin{tabular}{|c|c|c|c|c|c|}
\hline VARIABLES & $\begin{array}{c}(1) \\
\text { ROA }\end{array}$ & $\begin{array}{c}(2) \\
\text { Asset growth }\end{array}$ & $\begin{array}{c}(3) \\
\log (\text { Sales })\end{array}$ & $\begin{array}{c}(4) \\
\log (\text { Subs. })\end{array}$ & $\begin{array}{c}(5) \\
\log (\text { Countries })\end{array}$ \\
\hline IPO & $\begin{array}{l}0.190^{*} \\
(0.111)\end{array}$ & $\begin{array}{c}0.736 \\
(0.699)\end{array}$ & $\begin{array}{c}0.835 \\
(1.497)\end{array}$ & $\begin{array}{c}1.021^{* * *} \\
(0.349)\end{array}$ & $\begin{array}{c}0.260^{* * *} \\
(0.092)\end{array}$ \\
\hline IPO x High Fin. Dep. & $\begin{array}{l}0.045^{*} \\
(0.026)\end{array}$ & $\begin{array}{c}0.174 \\
(0.109)\end{array}$ & $\begin{array}{l}-0.162 \\
(0.333)\end{array}$ & $\begin{array}{c}-0.277^{* * *} \\
(0.065)\end{array}$ & $\begin{array}{c}-0.063^{* * *} \\
(0.018)\end{array}$ \\
\hline IPO x High Disclosure & $\begin{array}{l}0.022^{* *} \\
(0.011)\end{array}$ & $\begin{array}{c}0.096 \\
(0.075)\end{array}$ & $\begin{array}{l}-0.104 \\
(0.163)\end{array}$ & $\begin{array}{c}0.049 \\
(0.044)\end{array}$ & $\begin{array}{c}-0.062^{* * *} \\
(0.012)\end{array}$ \\
\hline IPO x High F.D. $x$ High Discl. & $\begin{array}{c}0.027 \\
(0.035)\end{array}$ & $\begin{array}{c}0.161 \\
(0.209)\end{array}$ & $\begin{array}{l}0.300 \\
(0.418)\end{array}$ & $\begin{array}{c}0.062 \\
(0.087)\end{array}$ & $\begin{array}{c}0.053^{* *} \\
(0.023)\end{array}$ \\
\hline Observations & 12,189 & 12,155 & 12,208 & 14,110 & 14,110 \\
\hline Number of firms & 3,195 & 3,048 & 3,141 & 3,467 & 3,467 \\
\hline Firm FE & Yes & Yes & Yes & Yes & Yes \\
\hline Event year FE & Yes & Yes & Yes & Yes & Yes \\
\hline SIC $x$ calendar year FE & Yes & Yes & Yes & Yes & Yes \\
\hline IPO month x Post FE & Yes & Yes & Yes & Yes & Yes \\
\hline Regression & Second stage & Second stage & Second stage & Second stage & Second stage \\
\hline Instrument \#1 & Pre-IPO ret $>0$ & Pre-IPO ret $>0$ & Pre-IPO ret $>0$ & Pre-IPO ret $>0$ & Pre-IPO ret $>0$ \\
\hline Instrument \#2 & $\begin{array}{l}\text { Pre-IPO ret }>0 \\
\text { x High Fin.Dep. }\end{array}$ & $\begin{array}{l}\text { Pre-IPO ret }>0 \\
\text { x High Fin.Dep. }\end{array}$ & $\begin{array}{l}\text { Pre-IPO ret }>0 \\
\text { x High Fin.Dep. }\end{array}$ & $\begin{array}{l}\text { Pre-IPO ret }>0 \\
\text { x High Fin.Dep. }\end{array}$ & $\begin{array}{l}\text { Pre-IPO ret }>0 \\
\text { x High Fin.Dep. }\end{array}$ \\
\hline Instrument \#3 & $\begin{array}{l}\text { Pre-IPO ret }>0 \\
\text { x High Discl. }\end{array}$ & $\begin{array}{c}\text { Pre-IPO ret }>0 \\
\text { x High Discl. }\end{array}$ & $\begin{array}{l}\text { Pre-IPO ret }>0 \\
\text { x High Discl. }\end{array}$ & $\begin{array}{c}\text { Pre-IPO ret }>0 \\
\text { x High Discl. }\end{array}$ & $\begin{array}{c}\text { Pre-IPO ret }>0 \\
\text { x High Discl. }\end{array}$ \\
\hline
\end{tabular}


Table A.9: Long-term Outcomes: Acquisitions

This table shows the second stage regressions results using the logarithm of one plus the number of acquisitions as the dependent variable. Post-IPO attempt acquisitions are adjusted to account for long-term outcomes using forward-looking moving averages (see Table A.2). Columns 2-4 also include the instrumented IPO dummy's interaction with cross-sectional dummies based on industry or country-level characteristics. Standard errors (in parentheses) are adjusted for heteroscedasticity and clustered at the firm level. Significant at: ${ }^{*} 10 \%$, $* * 5 \%$ and $* * * 1 \%$.

\begin{tabular}{|c|c|c|c|c|}
\hline VARIABLES & $\begin{array}{c}(1) \\
\log (\text { acquisition })\end{array}$ & $\begin{array}{c}(2) \\
\log (\text { acquisition })\end{array}$ & $\begin{array}{c}(3) \\
\log (\text { acquisition })\end{array}$ & $\begin{array}{c}(4) \\
\log (\text { acquisition })\end{array}$ \\
\hline IPO & $\begin{array}{c}0.002 \\
(0.179)\end{array}$ & $\begin{array}{c}0.066 \\
(0.164)\end{array}$ & $\begin{array}{c}0.064 \\
(0.161)\end{array}$ & $\begin{array}{c}0.071 \\
(0.170)\end{array}$ \\
\hline IPO x High Ind. Fin. Dep & & $\begin{array}{c}-0.0084^{* * *} \\
(0.027)\end{array}$ & & \\
\hline IPO x High Anti self-dealing & & & $\begin{array}{l}-0.019 \\
(0.020)\end{array}$ & \\
\hline IPO x High Disclosure & & & & $\begin{array}{c}-0.015 \\
(0.020)\end{array}$ \\
\hline Observations & 14,110 & 14,110 & 14,110 & 14,110 \\
\hline Number of firms & 3,467 & 3,467 & 3,467 & 3,467 \\
\hline Firm FE & Yes & Yes & Yes & Yes \\
\hline Event year FE & Yes & Yes & Yes & Yes \\
\hline SIC x calendar year FE & Yes & Yes & Yes & Yes \\
\hline IPO month x Post FE & Yes & Yes & Yes & Yes \\
\hline Regression & Second stage & Second stage & Second stage & Second stage \\
\hline Instrument \#1 & Pre-IPO ret $>0$ & Pre-IPO ret $>0$ & Pre-IPO ret $>0$ & Pre-IPO ret $>0$ \\
\hline Instrument \#2 & & $\begin{array}{l}\text { Pre-IPO ret }>0 \\
\text { x High Fin.Dep. }\end{array}$ & $\begin{array}{l}\text { Pre-IPO ret }>0 \\
x \text { High anti-sd }\end{array}$ & $\begin{array}{c}\text { Pre-IPO ret }>0 \\
\text { x High discl. }\end{array}$ \\
\hline
\end{tabular}


Table A.10: Long-term Outcomes: Being Target of an Acquisition

This table shows the second stage regressions results using a dummy variable for whether the IPO-attempt firm was the target of an acquisition during the five years following an IPO attempt (see Table A.2). Columns 2-4 also include the instrumented IPO dummy's interaction with cross-sectional dummies based on industry or country-level characteristics. Standard errors (in parentheses) are adjusted for heteroscedasticity and clustered at the firm level. Significant at: ${ }^{*} 10 \%, * * 5 \%$ and ${ }^{* * *} 1 \%$.

\begin{tabular}{|c|c|c|c|c|}
\hline VARIABLES & $\begin{array}{c}(1) \\
\text { Target of Acq. }\end{array}$ & $\begin{array}{c}(2) \\
\text { Target of Acq. }\end{array}$ & $\begin{array}{c}(3) \\
\text { Target of Acq. }\end{array}$ & $\begin{array}{c}(4) \\
\text { Target of Acq. }\end{array}$ \\
\hline IPO & $\begin{array}{c}0.061 \\
(0.103)\end{array}$ & $\begin{array}{c}0.063 \\
(0.095)\end{array}$ & $\begin{array}{c}0.074 \\
(0.093)\end{array}$ & $\begin{array}{c}0.081 \\
(0.098)\end{array}$ \\
\hline IPO x High Ind. Fin. Dep & & $\begin{array}{l}-0.013 \\
(0.015)\end{array}$ & & \\
\hline IPO x High Anti self-dealing & & & $\begin{array}{l}-0.021^{*} \\
(0.011)\end{array}$ & \\
\hline IPO x High Disclosure & & & & $\begin{array}{l}-0.016 \\
(0.012)\end{array}$ \\
\hline Observations & 14,110 & 14,110 & 14,110 & 14,110 \\
\hline Number of firms & 3,467 & 3,467 & 3,467 & 3,467 \\
\hline Firm FE & Yes & Yes & Yes & Yes \\
\hline Event year FE & Yes & Yes & Yes & Yes \\
\hline SIC x calendar year FE & Yes & Yes & Yes & Yes \\
\hline IPO month x Post FE & Yes & Yes & Yes & Yes \\
\hline Regression & Second stage & Second stage & Second stage & Second stage \\
\hline Instrument \#1 & Pre-IPO ret $>0$ & Pre-IPO ret $>0$ & Pre-IPO ret $>0$ & Pre-IPO ret $>0$ \\
\hline Instrument \#2 & & $\begin{array}{l}\text { Pre-IPO ret }>0 \\
\text { x High Fin.Dep. }\end{array}$ & $\begin{array}{l}\text { Pre-IPO ret }>0 \\
x \text { High anti-sd }\end{array}$ & $\begin{array}{c}\text { Pre-IPO ret }>0 \\
\text { x High discl. }\end{array}$ \\
\hline
\end{tabular}

